\title{
Synthesis, Antibacterial Activity and DFT Calculation of Naphtopyrano, Furo and Pyrazolo [3,2,e] [1,2,4]Triazolo-[1,5-c]Pyrimidine Derivatives
}

\author{
Dhiab Jabli ${ }^{1} \cdot \operatorname{Rim}_{\text {Milad }^{2}} \cdot$ Manef Abderrabba $^{2} \cdot$ Mohamed Lotfi Efrit $^{1}$
}

Received: 5 February 2019 / Accepted: 1 July 2019 / Published online: 8 August 2019

(c) The Author(s) 2019

\begin{abstract}
A new series of $3 N$-substituted triazolo-[1,5-c]pyrimidine 7, 8 and 9 have been synthesized in good yields (78-91\%) trough a facile method using substituted 2-amino-3-cyano-pyrans 1, 2-amino-3-cyano-4-methylfuran 2, 1-Phenyl-3-thiomethyl5-aminopyrazole-4-carbonitrile $\mathbf{3}$ as building block and cyanoacetic acid hydrazide as reagent in one framework. The structure of the synthesized compounds was established on the basis of their mass, spectral data and DFT at B3LYP.
\end{abstract}

\section{Graphic Abstract}



Keywords Naphthopyranotriazolopyrimidines phosphonates $\cdot$ Aminopyrazole $\cdot \alpha$-Fonctionalized iminoethers and pyrimidine

\section{Introduction}

Pyrano, furano and pyrazolopyrimidine are priviliged structures, which attracted considerable attention in the designing of biologically active molecules. Pyranotriazolopyrimidine derivatives have attracted a great deal of interest due to their biological activities and their potential applications as pharmacological agents. Several derivatives of the pyranotriazolopyrimidine exhibit platelet anti-aggregating activity and local "inhibition of influenza, virus sialidase and mutagenic

Dhiab Jabli

jabli.dhiab@gmail.com

1 Laboratory of Selective Organic and Heterocyclic Synthesis-Biological Activity Evaluation, Department of Chemistry, Faculty of Sciences, El Manar University, El Manar II, 1060 Tunis, Tunisia

2 Laboratoire Matériaux, Molécules et applications, Institut Préparatoire aux Etudes Scientifiques et Techniques, BP, La Marsa, Tunisia activity [1], anti-genotoxic activity [2], antimicrobial activity [3], AChE or acetylhydrolase inhibition [4], and antifungal [5, 6]". Moreover pyranotriazolopyrimidine derivatives are well known antigenotoxic, [7] and in the agrochemical field, showing herbicidal activity [8]. Among these heterocyclic, the furopyrimidine derivatives are an important class of heterocyclic compounds in pharmaceutical discovery research such that antiphlogistic activity [9], antibacterial [5], anti-inflammatory [10], and herbicidal activities [11]. Recently, some furopyrimidines were shown to be potent VEGFR2 and EGFR [12]. Furthermore, 1,2,4-triazolopyrimidines derivatives has received considerable attention among synthetic chemists because molecules bearing this structural feature have been found to display a wide range of potent biological activities in medicinal chemistry, as antibacterial, antifungal, [13,14] antiplatelet, antithrombotic, [15] anti-inflammatory and analgesic agents, [16] and in the agrochemical field, showing herbicidal activity [8]. According to these encouraging results and as a continuation of our 




Scheme 1 General reactions

interest works on heterocyclic compounds related to (pyrano, furano and pyrzolo)pyrimidines [17, 18], we wish to report herein the synthesis of new pyranotriazolopyrimidine $\mathbf{7}$, furanotriazolopyrimidine $\mathbf{8}$ and pyrazolotriazolopyrimidine 9 in the hope of obtaining compounds of diverse biological activities. Hence a facile method has been attempted by incorporating triazole and pyrimidine rings with substituted 2-amino-3-cyano-pyrans 1, 2-amino-3-cyano-4-methylfuran 2, 1-Phenyl-3-thiomethyl-5-aminopyrazole-4-carbonitrile 3, as building block in one framework (Scheme 1). Also, the compounds were investigated theoretically by density functional theory DFT and time-dependant density functional theory TD-DFT. (TDDFT) extends the basic thoughts of ground-state density-functional theory (DFT) to the treatment of excitations or more general time-dependent phenomena $[19,20]$.

\section{Experimental Methods}

\subsection{General}

Solvents and reagents were obtained from commercial sources and were dried and purified when necessary by standard techniques. Melting points were taken with a Kofler hot staged apparatus and are uncorrected. All reactions were monitored by thin layer chromatography (TLC) using precoated aluminium sheet silica gel Merck 60 F 254 and was visualized by UV lamp. IR spectra were carried out in the liquid state dissolved in chloroform with Perkin Elmer Paragon 1000 PC spectrometer or in solid state dispersion in KBr with a Perkin Elmer 1600 series FT-IR spectrometer. ${ }^{1} \mathrm{H}$ and ${ }^{13} \mathrm{C}$ NMR spectra were recorded on a Varian-Unity spectrometer at $300 \mathrm{MHz}(300 \mathrm{MHz}$ and $75 \mathrm{MHz}$, respectively) using TMS as an internal standard. Chemical shifts of protons were reported in parts per million (ppm) downfield from TMS. Coupling constants are reported in Hertz $(\mathrm{Hz})$.
Elemental analyses were determined using an elementar vario EI III Elemental Analyser.

\subsubsection{Synthesis of Cyanoacetic Acid Hydrazide}

Cyanoacetic acid hydrazide was obtained according to the published method in literature [26] by careful addition of $9.91 \mathrm{~g}(0.10 \mathrm{~mol})$ of ethyl cyanoacetate to hydrazine hydrate $(5.00 \mathrm{~g}, 0.10 \mathrm{~mol})$ with stirring at room temperature. The formed cyanoacetic acid hydrazide was filtered, washed with Et2O, and dried (Mp: $108-110{ }^{\circ} \mathrm{C}$. Yield: $90 \%$ ).

\subsubsection{Synthesis of 2-Amino-4-Aryl-3-Cyano-4H-Naphto-[2, 1-b]-Pyrans 1}

The required naphto[2,1-b]pyrans 1 were obtained using known experimental procedures developed previously by Messaâd et al. [21, 22]. Following this typical experiment, a mixture of 2-naphtol $(0.01 \mathrm{mmol}, 1.5 \mathrm{~g})$ and arylalkylidenmalononitrile $(0.01 \mathrm{mmol}, 1.7 \mathrm{~g})$ in ethanol $(30 \mathrm{~mL})$ was refluxed for $10 \mathrm{~h}$ with the presence of ( 0.2 equivalent) of piperidine. The solvent was evaporated to dryness under reduced pressure. The solid was collected by filtration and purified by recrystallization from toluene (Scheme 2).

\subsubsection{2-Amino-3-Cyano-4-(p-Chlorophenyl)-4H-Napht} o-[2,1-b]-Pyran 1a [21, 22] Yield: 68\%; Mp: $231{ }^{\circ} \mathrm{C}$. IR ( $\left.\max , \mathrm{cm}^{-1}\right): 3412,3331,2178 \mathrm{~cm}^{-1} .{ }^{1} \mathrm{H}$ NMR $(300 \mathrm{MHz}$, DMSO- $\left.d_{6}+\mathrm{CDCl}_{3}\right) \delta: 7.11-7.95(\mathrm{~m}, 10 \mathrm{H}), 6.87$ (br, s, 2H), $5.09(\mathrm{~s}, 1 \mathrm{H})$.

2.1.2.2 2-Amino-3-Cyano-4-(3,4-Dichlorophenyl)-4H-Nap hto-[2,1-b]-Pyran 1b [21, 22] Yield: 72\%. Mp: $219{ }^{\circ} \mathrm{C}$. IR ( $\left.\max , \mathrm{cm}^{-1}\right): 3417,3321,2193 \mathrm{~cm}^{-1} .{ }^{1} \mathrm{H} \mathrm{NMR}(300 \mathrm{MHz}$, DMSO- $\left.d_{6}+\mathrm{CDCl}_{3}\right) \delta: 7.40$ (br, s, 2H), 7.18-8.04 (m, 9H), $5.16(\mathrm{~s}, 1 \mathrm{H})$. 
Scheme 2 Synthesis of starting materials 4, 5 and 6
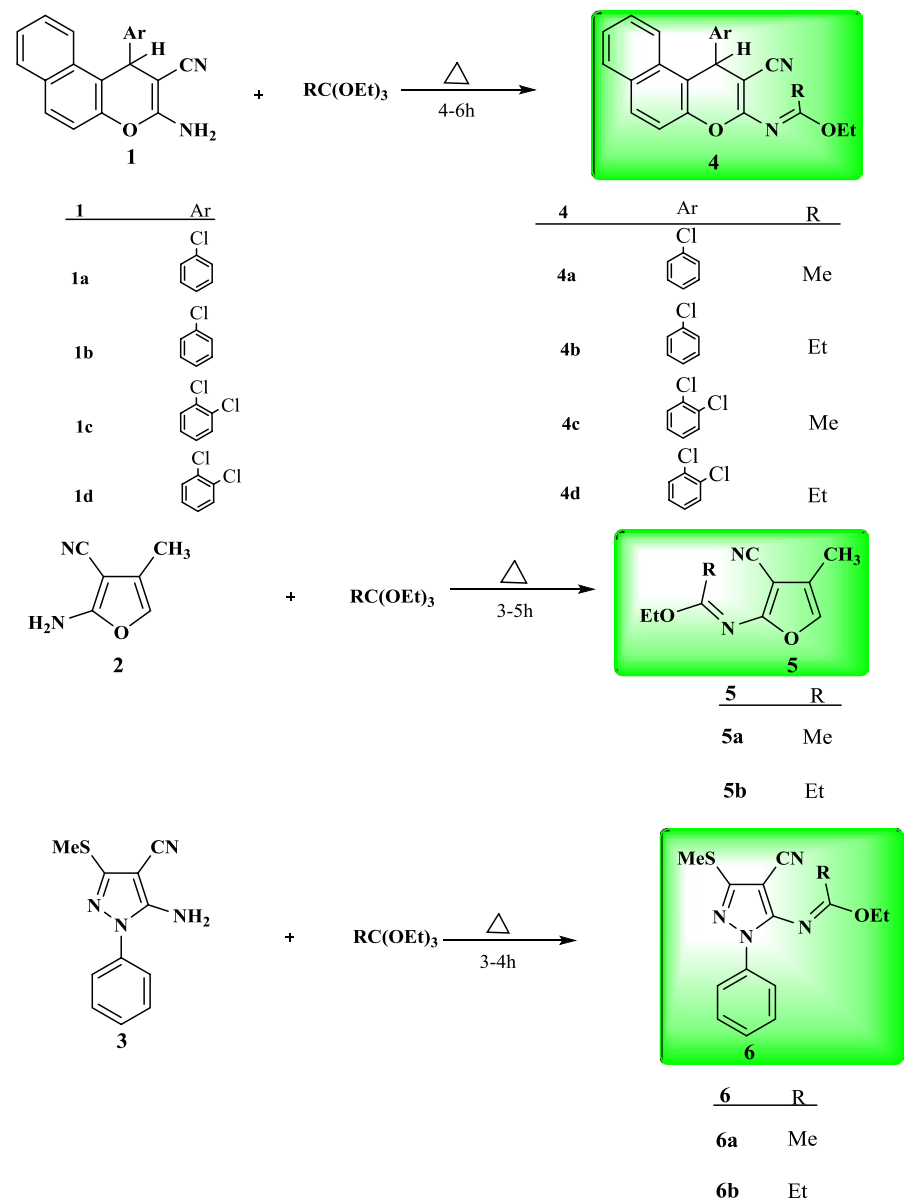

\subsubsection{Synthesis of 5-Amino-3-(Methylthio)-1-Phe- nyl-1H-Pyrazole-4-Carbonitrile 3 [26]}

Acetol (3.7 g, $50 \mathrm{mmol})$ was dissolved in methanol (20 mL) with stirring under an atmosphere of nitrogene and a mixture of malononitrile $(3.5 \mathrm{~g}, 53 \mathrm{mmol})$ and triethylamine $(6.96 \mathrm{~mL}, 0 \mathrm{mmol})$ in methanol $(25 \mathrm{~mL})$ was added slowly drop-wise at such as rate as to maintain the reaction temperature below $0{ }^{\circ} \mathrm{C}$. After, the reaction mixture was diluted with water $(50 \mathrm{~mL})$ and extracted with methylene chloride $(2 \times 50 \mathrm{~mL})$. The organic layers were combined, dried $\left(\mathrm{MgSO}_{4}\right)$ and condensed to a brown solid. Recrystalysed from ethyl acetate-hexane gave 2 .

2.1.3.1 2-Amino-3-Cyano-4-Methylfuran 2 [23] Yield: 61\%. Mp: $158-159{ }^{\circ} \mathrm{C}$. IR $\left(\nu \max , \mathrm{cm}^{-1}\right): \nu_{\mathrm{NH} 2}=3345-$ $3451 ; v_{\mathrm{CN}}=2210 ; v_{\mathrm{C}=\mathrm{C}}=1591 .{ }^{1} \mathrm{H}-\mathrm{NMR}(300 \mathrm{MHz}$, DMSO- $\left.d_{6}\right) \delta 6.49(\mathrm{~s}, 1 \mathrm{H},=\mathrm{CH}), 5.76\left(\mathrm{br}, \mathrm{s}, 2 \mathrm{H}, \mathrm{NH}_{2}\right.$ ), $2.12\left(\mathrm{~s}, 3 \mathrm{H}, \mathrm{CH}_{3}\right) .{ }^{13} \mathrm{C}-\mathrm{NMR}\left(75 \mathrm{MHz}, \mathrm{DMSO}-d_{6}\right) \delta: 20.2$, 24.1, 29.3, 120.4, 127.3, 129.8 .
To a mixture of ( $0.03 \mathrm{~mol})$ of 2-(bis-methylsulfanylmethylene)malononitrile and $(0.03 \mathrm{~mol})$ of phenyl hydrazine in $(20 \mathrm{~mL})$ ethanol were added drop wise with stirring a solution of diethyl amine or morpholine $(2 \mathrm{~mL})$ in ethanol $(5 \mathrm{~mL})$. When addition was completed; the mixture was stirred at a temperature of $80{ }^{\circ} \mathrm{C}$ to reflux for $9 \mathrm{~h}$. The heating and stirring were still left $1 \mathrm{~h}$. The remaining solids were recrystallized from isopropanol to produce the pure compound $\mathbf{3}$ (Scheme 1).

2.1.4.1 1-Phenyl-3-(Methylthio)-5-Aminopyrazole-4-Carbonitrile 3 Yield: $81 \%$. Mp: ${ }^{134-136}{ }^{\circ} \mathrm{C},{ }^{1} \mathrm{H}-\mathrm{NMR}$ $\left(300 \mathrm{MHz}, \mathrm{DMSO}-d_{6}+\mathrm{CDCl}_{3}\right): \delta: 7.36-7.68(\mathrm{~m}, 5 \mathrm{H}, \mathrm{Ph})$, $6.21\left(\mathrm{br} \mathrm{s}, 2 \mathrm{H}, \mathrm{NH}_{2}\right), 2.67$ (s, 3H, $\mathrm{SCH}_{3}$ ).

\subsubsection{Synthesis of Iminoethers 4, 5 and 6 [28-30]}

A mixture of compounds $\mathbf{1}, \mathbf{2}$ and $\mathbf{3}(5 \mathrm{mmol})$ and excess of ethyl orthoester $(10 \mathrm{~mL})$ was heated under reflux for $4-10 \mathrm{~h}$ 
in the presence of few drops of glacial acetic acid. After removing liberated ethanol and excess of ethyl orthoester under vacuum, we get either a solid that was purified by recrystallization $(\mathrm{EtOH})$ or an oil which was distilled under reduced pressure.

\subsubsection{N-[1-(4-Chloro-Phenyl)-2-Cyano-1H-Benzo[f]} chromen-3-yl]-Acetimidic Acid Ethyl Ester 4a Yield: 60\%; Mp $109-111{ }^{\circ} \mathrm{C}$; IR $\left(\nu \max , \mathrm{cm}^{-1}\right) 2200(\mathrm{C} \equiv \mathrm{N}), 1658$ $(\mathrm{C}=\mathrm{N}) .{ }^{1} \mathrm{H}$ NMR $\left(300 \mathrm{MHz}, \mathrm{DMSO}-d_{6}\right) \delta: 7.19-7.85$ (m, $10 \mathrm{H}, \operatorname{Ar}-\mathrm{H}) ; 5.32$ (s, 1H), 4.31 (q, ${ }^{3} J=7.2 \mathrm{~Hz}, 2 \mathrm{H}$, $\left.\mathrm{OCH}_{2} \mathrm{CH}_{3}\right), 2.11\left(\mathrm{~s}, 3 \mathrm{H}, \mathrm{CH}_{3}\right), 1.37\left(\mathrm{t},{ }^{3} J=7.2 \mathrm{~Hz}, 3 \mathrm{H}\right.$, $\left.\mathrm{OCH}_{2} \mathrm{CH}_{3}\right) .{ }^{13} \mathrm{C}$ NMR (75 MHz, DMSO- $d_{6}$ ) $\delta: 16.2,20.1$, 25.3, 32.4, 102.6, 110.4, 110.4, 111.9, 111.8, 112.1, 112.8, $116.7,120.8,121.0,131.6,134.6,137.5,141.8,143.9$, $145.4,148.6,153.3,157.3,163.1$.

2.1.5.2 N-[1-(4-Chloro-Phenyl)-2-Cyano-1H-Benzo[f] chromen-3-yl]-Propiomidic Acid Ethyl Ester 4b Yield: 95\%; Mp $108{ }^{\circ} \mathrm{C}$; IR $\left(\nu \max , \mathrm{cm}^{-1}\right) 2203(\mathrm{C} \equiv \mathrm{N}), 1652(\mathrm{C}=\mathrm{N}) .{ }^{1} \mathrm{H}$ NMR (300 MHz, DMSO-d $\left.{ }_{6}+\mathrm{CDCl}_{3}\right) \delta: 7.17-7.84(\mathrm{~m}, 9 \mathrm{H}$, $\mathrm{Ar}-\mathrm{H}) ; 5.32(\mathrm{~s}, 1 \mathrm{H}), 4.31\left(\mathrm{q},{ }^{3} J=7.2 \mathrm{~Hz}, 2 \mathrm{H}, \mathrm{OCH}_{2} \mathrm{CH}_{3}\right)$ $2.39\left(\mathrm{q},{ }^{3} \mathrm{~J}=7.2 \mathrm{~Hz}, 2 \mathrm{H}, \mathrm{CH}_{2} \mathrm{CH}_{3}\right), 1.36\left(\mathrm{t},{ }^{3} \mathrm{~J}=7.2 \mathrm{~Hz}, 3 \mathrm{H}\right.$, $\left.\mathrm{OCH}_{2} \mathrm{CH}_{3}\right), 1.20\left(\mathrm{t},{ }^{3} \mathrm{~J}=7.2 \mathrm{~Hz}, 3 \mathrm{H}, \mathrm{CH}_{2} \mathrm{CH}_{3}\right) .{ }^{13} \mathrm{C}$ NMR (75 MHz, DMSO-d ${ }_{6}$ ) $\delta: 17.3,21.2,26.4,32.3,102.4,111.6$, $111.6,112.4,112.4,113.2,113.8,116.5,121.1,122.0$, $131.4,133.5,138.3,142.4,143.9,146.2,148.7,154.6$, $157.3,164.2$.

2.1.5.3 N-[2-(4-Cyano-1-(3,4-Dichloro-Phenyl)-1H-Benz o[f]chromen-3-yl]-Acetimidic Acid Ethyl Ester 4c Yield: 60\%; Mp 114-115 ${ }^{\circ} \mathrm{C}$; IR $\left(\nu \max , \mathrm{cm}^{-1}\right) 2214(\mathrm{C} \equiv \mathrm{N}), 1662$ $(\mathrm{C}=\mathrm{N}) .1 \mathrm{H} \mathrm{NMR}\left(300 \mathrm{MHz}, \mathrm{CDCl}_{3}\right) \delta: 7.13-7.62(\mathrm{~m}, 10 \mathrm{H}$, $\mathrm{Ar}-\mathrm{H}), 5.23(\mathrm{~s}, 1 \mathrm{H}), 4.13\left(\mathrm{q},{ }^{3} \mathrm{~J}=7.2 \mathrm{~Hz}, 2 \mathrm{H}, \mathrm{OCH}_{2} \mathrm{CH}_{3}\right.$ ), $2.08\left(\mathrm{~s}, 3 \mathrm{H}, \mathrm{CH}_{3}\right), 1.41\left(\mathrm{t},{ }^{3} \mathrm{~J}=7.2 \mathrm{~Hz}, 3 \mathrm{H}, \mathrm{OCH}_{2} \underline{\mathrm{CH}}_{3}\right) .{ }^{13} \mathrm{C}$ NMR (75 MHz, $\mathrm{CDCl}_{3}$ ) $\delta: 17.8,23.1,27.1,34.1,102.5$, $111.7,111.7,113.1,113.1,113.1,113.9,115.6,123.2$, $123.7,132.8,137.3,140.0,142.7,144.9,147.2,150.2$, 153.6, 158.1, 164.1.

2.1.5.4 N-[2-(4-Cyano-1-(3,4-Dichloro-Phenyl)-1H-Benz o[f]chromen-3-yl]-Propiomidic Acid Ethyl Ester 4d Yield: 95\%; Mp $116{ }^{\circ} \mathrm{C}$; IR $\left(\nu \max , \mathrm{cm}^{-1}\right) 2212(\mathrm{C} \equiv \mathrm{N}), 1659$ $(\mathrm{C}=\mathrm{N}) .{ }^{1} \mathrm{H}$ NMR $\left(300 \mathrm{MHz}, \mathrm{DMSO}-d_{6}+\mathrm{CDCl}_{3}\right) \delta: 7.23-$ $7.76(\mathrm{~m}, 9 \mathrm{H}, \mathrm{Ar}-\mathrm{H}) ; 5.17$ (s, 1H), 4.23 (q, ${ }^{3} \mathrm{~J}=7.2 \mathrm{~Hz}$, $2 \mathrm{H}, \mathrm{OCH}_{2} \mathrm{CH}_{3}$ ), 2.41 (q, $\left.{ }^{3} \mathrm{~J}=7.2 \mathrm{~Hz}, 2 \mathrm{H}, \mathrm{CH}_{2} \mathrm{CH}_{3}\right), 1.31$ $\left(\mathrm{t},{ }^{3} \mathrm{~J}=7.2 \mathrm{~Hz}, 3 \mathrm{H}, \mathrm{OCH}_{2} \mathrm{CH}_{3}\right), 1.18\left(\mathrm{t},{ }^{3} \mathrm{~J}=7.2 \mathrm{~Hz}, 3 \mathrm{H}\right.$, $\left.\mathrm{CH}_{2} \mathrm{CH}_{3}\right) .{ }^{13} \mathrm{C}$ NMR (75 MHz, DMSO- $\left.d_{6}+\mathrm{CDCl}_{3}\right) \delta$ : 18.1, 23.2, 27.2, 32.5, 103.0, 110.7, 110.7, 112.3, 112.3, $112.7,112.7,115.6,121.3,121.9,132.1,133.4,137.6$, 144.6, 145.9, 148.2, 150.4, 154.4, 158.2, 165.7.
2.1.5.5 N-(3-Cyano-4-Methyl-Furan-2-yl)-Acetimidic Acid Ethyl Ester 5a Yield: $82 \%$. Mp: $87-88{ }^{\circ} \mathrm{C}$. IR $\left(\mathrm{CHCl}_{3}\right)$ : $2214,1645 \mathrm{~cm}^{-1} .{ }^{1} \mathrm{H}-\mathrm{NMR}\left(300 \mathrm{MHz}, \mathrm{DMSO}-d_{6}\right) \delta: 7.08$ (s, $1 \mathrm{H}), 4.13\left(\mathrm{q}, \mathrm{J}=7.2 \mathrm{~Hz}, 2 \mathrm{H}, \mathrm{OCH}_{2} \mathrm{CH}_{3}\right), 2.13(\mathrm{~m}, 6 \mathrm{H}$, $\left.\mathrm{CH}_{3}\right), 1.37(\mathrm{~s}, 3 \mathrm{H}) .{ }^{13} \mathrm{C}-\mathrm{NMR}\left(75 \mathrm{MHz}, \mathrm{DMSO}-d_{6}\right) \delta$ : 18.1, 22.3, 26.7, 60.3, 116.8, 125.2, 128.6, 140.1, 150.3, 165.7 .

2.1.5.6 N-(3-Cyano-4-Methyl-Furan-2-yl)-Propiomidic Acid Ethyl Ester 5b Yield: $82 \%$. Mp: $108-109{ }^{\circ} \mathrm{C}$. IR $\left(\mathrm{CHCl}_{3}\right)$ : 2214 and $1645 \mathrm{~cm}^{-1}$. ${ }^{1} \mathrm{H}-\mathrm{NMR}$ (300 MHz, DMSO- $d_{6}$ ) $\delta$ : $6.76(\mathrm{~s}, 1 \mathrm{H}), 3.87$ (q, J=7.2 Hz, 4H, $\left.\mathrm{CH}_{2}\right), 2.34$ (s, 3H, $\left.\mathrm{CH}_{3}\right), 1.41(\mathrm{t}, 6 \mathrm{H}) .{ }^{13} \mathrm{C}-\mathrm{NMR}\left(75 \mathrm{MHz}, \mathrm{DMSO}-d_{6}\right) \delta: 16.6$, $16.8,22.3,30.3,62.6,115.7,123.5,128.3,141.3,151.7$, 165.9 .

2.1.5.7 N-(4-Cyano-5-Methylsulfanyl-2-Phenyl-2H-Pyrazol-3-yl)-Acetimidic Acid Ethyl Ester 6a Yield: 81\%, Mp: $94{ }^{\circ} \mathrm{C},{ }^{1} \mathrm{H}-\mathrm{NMR}\left(\mathrm{CDCl}_{3}\right): \delta=7.26-7.74(\mathrm{~m}, 5 \mathrm{H}, \mathrm{Ph})$, $4.13\left(\mathrm{q}, 2 \mathrm{H}, \mathrm{O}-\mathrm{CH}_{2}-\mathrm{CH}_{3}\right), 3.31$ (s, $\left.3 \mathrm{H},-\mathrm{SCH}_{3}\right), 3.23$ (q, $\left.3 \mathrm{H}, \mathrm{O}-\mathrm{CH}_{2}-\mathrm{CH}_{3}\right) .1 .31\left(\mathrm{~s}, 3 \mathrm{H}, \mathrm{CH}_{3}\right) \cdot{ }^{13} \mathrm{C}-\mathrm{NMR}(75 \mathrm{MHz}$, DMSO- $\left.d_{6}+\mathrm{CDCl}_{3}\right): 18.35,25.26,42.31,103.31,113.2$, 113.6, 113.85, 115.59, 126.7, 126.9, 137.15, 140.12; 140.7, $148.05 ; 151.38$.

2.1.5.8 N-(4-Cyano-5-Methylsulfanyl-2-Phenyl-2H-Pyrazol-3-yl)-Propiomidic Acid Ethyl Ester 6b Yield: 81\%, Mp: $102{ }^{\circ} \mathrm{C},{ }^{1} \mathrm{H}-\mathrm{NMR}\left(300 \mathrm{MHz}, \mathrm{DMSO}-d_{6}+\mathrm{CDCl}_{3}\right): \delta=7.26-$ $7.74(\mathrm{~m}, 5 \mathrm{H}, \mathrm{Ph}), 4.26\left(\mathrm{q}, 2 \mathrm{H}, \mathrm{O}-\mathrm{CH}_{2}-\mathrm{CH}_{3}\right), 2.46-2.50$ $\left(\mathrm{s}, 3 \mathrm{H},-\mathrm{SCH}_{3}\right), 2.6\left(\mathrm{~s}, 3 \mathrm{H},-\mathrm{CH}_{3}\right), 2.21\left(\mathrm{~m}, 2 \mathrm{H},-\mathrm{CH}_{2}-\right.$ $\left.\mathrm{CH}_{3}\right), 1.36\left(\mathrm{~m}, 6 \mathrm{H},-\mathrm{CH}_{3}\right) .{ }^{13} \mathrm{C}-\mathrm{NMR}(75 \mathrm{MHz}$, DMSO$\left.d_{6}+\mathrm{CDCl}_{3}\right): 17.17,18.24,24.38,42.52,102.63,113.47$, $113.76,113.87,115.71,125.8,126.0,138.23,141.31$; $141.73,149.12 ; 153.21$.

\subsubsection{Synthesis of Naphtopyranotriazolopyrimidines 7}

A mixture of $4(20 \mathrm{mmol})$ and hydrazine hydrate $(5 \mathrm{~mL})$ in ethanol $(15 \mathrm{~mL})$ was refluxed during $7 \mathrm{~h}$, and then left to cool. The solid obtained was collected by filtration and purified by recrystallization from toluene (Scheme 2), washed with ethanol, dried and crystallized from ethanol to give pale yellow crystals 4-iminopyranopyrimidine $\mathbf{7}^{\prime}$. To a solution of compounds $\mathbf{7}^{\prime}(10 \mathrm{mmol})$ in Toluene $(50 \mathrm{~mL})$ containing $\mathrm{TsOH}(0.1 \mathrm{~g})$ as catalyst, was added ethyl cyanoacetate $(10 \mathrm{mmol})$. The reaction mixture was heated under reflux overnight. The mixture was then poured onto ice/water and the formed solid pyranotriazolopyrimidine derivatives $\mathbf{7}$ collected by filtration and recrystallized from ethanol/water. 
2.1.6.1 2-Cyanomethyl-5-Methyl-1-(4-Chloro-Phenyl)1H-Benzo[f]Chromene[3,2e][1,2,4]Triazolo[1,5-c]Pyrimidine 7a Yield: 77\%. Mp: 202-204 ${ }^{\circ} \mathrm{C}$. IR: 3081, 2972, 2211, 1656, 1630, 1587, 1571, 1453, 771, $743 \mathrm{~cm}^{-1}$. ${ }^{1} \mathrm{H}-\mathrm{NMR}\left(300 \mathrm{MHz}, \mathrm{CDCl}_{3}+\mathrm{DMSO}_{6}\right) \quad \delta: 7.56-7.37$ $(\mathrm{m}, 10 \mathrm{H}), 6.42(\mathrm{~s}, 1 \mathrm{H}), 4.18(\mathrm{~s}, 2 \mathrm{H}), 2.54(\mathrm{~s}, 3 \mathrm{H}) \cdot{ }^{13} \mathrm{C}$ NMR (75 MHz, DMSO-d ${ }_{6}+\mathrm{CDCl}_{3}$ ) $\delta: \mathrm{C}_{1}, 20.4 ; \mathrm{C}_{2}, 31.6$; $\mathrm{C}_{4}, 30,2 ; \mathrm{C}_{6}, 102.2, \mathrm{C}_{7}, 114.3, \mathrm{C}_{8}, 117.6, \mathrm{C}_{5}, 123.5, \mathrm{C}_{9}-$ $\mathrm{C}_{14}, 125.3,127.5,128.5, \mathrm{C}_{15}-\mathrm{C}_{20}, 128.7,130.2,130.2$, 131.2, 131.6, $\mathrm{C}_{21}, 142.0, \mathrm{C}_{22}, 148.0, \mathrm{C}_{23}, 149.8, \mathrm{C}_{24}, 156.1$, $\mathrm{C}_{25}, 157.7, \mathrm{C}_{26}, 160,9$. Anal. Calcd for $\left(\mathrm{C}_{25} \mathrm{H}_{15} \mathrm{ClN}_{5} \mathrm{O}\right)$ 436.8805: C, 68.732; H, 3.461; N, 16.031. Found: C, $68.72 ; \mathrm{H}, 3.48 ; \mathrm{N}, 16.01$.

2.1.6.2 2-Cyanomethyl-5-Ethyl-1-(4-Chloro-Phenyl)1H-Benzo[f]Chromene[3,2e][1,2,4]Triazolo [1,5-c]Pyrimidine 7b Yield: $84 \%$. Mp: $180-181{ }^{\circ} \mathrm{C}$. IR: 3093, 2983 , 2221, 1645, 1620, 1596, 1574, 1450, 771, $728 \mathrm{~cm}^{-1}$. ${ }^{1} \mathrm{H}-\mathrm{NMR}\left(300 \mathrm{MHz}, \mathrm{CDCl}_{3}+\right.$ DMSO-d $_{6}$ ) $\delta:$ 7.84-8.13 $(\mathrm{m}, 10 \mathrm{H}), 6.74(\mathrm{~s}, 1 \mathrm{H}), 4.21(\mathrm{~s}, 2 \mathrm{H}), 2.57(\mathrm{~s}, 3 \mathrm{H}), 1.29$ (t, $3 \mathrm{H}, \mathrm{J}=7.2) .{ }^{13} \mathrm{C}$ NMR (75 MHz, DMSO-d $\mathrm{d}_{6}+\mathrm{CDCl}_{3}$ ) $\delta: \mathrm{C}_{1}, 18.7, \mathrm{C}_{2}, 25.1, \mathrm{C}_{3}, 32.4, \mathrm{C}_{4}, 32,2 ; \mathrm{C}_{6}, 102.2, \mathrm{C}_{7}, 114.3$, $\mathrm{C}_{8}, 117.6, \mathrm{C}_{5}, 123.5, \mathrm{C}_{9}-\mathrm{C}_{14}, 125.3-128.5, \mathrm{C}_{15}-\mathrm{C}_{20}, 128.7-$ 131.6, $\quad \mathrm{C}_{21}, 141.5, \quad \mathrm{C}_{22}, 142.1, \quad \mathrm{C}_{23}, 149.2, \quad \mathrm{C}_{24}, 149.8$, $\mathrm{C}_{25}, 155.7, \mathrm{C}_{26}, 157.6$. Anal. Calcd for $\left(\mathrm{C}_{26} \mathrm{H}_{18} \mathrm{ClN}_{5} \mathrm{O}\right)$ 450.9073: C, 69.257; H, 3.8; N, 15.532. Found: C, 69.30; H, 3.76; N, 15.49.

2.1.6.3 2-Cyanomethyl-5-Methyl-1-(3,4-Dichloro-Phenyl) -1H-Benzo[f]Chromene[3,2e][1,2,4]Triazolo [1,5-c]Pyrimidine 7c Yield: $81 \%$. Mp: 217-219 ${ }^{\circ} \mathrm{C}$. IR: 3057, 2977, 2218, 1661, 1632, 1583, 1568, 1454, 781, $732 \mathrm{~cm}^{-1} .{ }^{1} \mathrm{H}-$ NMR $\left(300 \mathrm{MHz}, \mathrm{CDCl}_{3}+\mathrm{DMSO}_{6}\right.$ ) $\delta: 7.69-7.48(\mathrm{~m}$, 9H), 6.46 (s, 1H), 4.27 (s, 2H), 2.48 (s, 3H). ${ }^{13} \mathrm{C}$ NMR (75 MHz, DMSO-d ${ }_{6}+\mathrm{CDCl}_{3}$ ) $8: \mathrm{C}_{1}, 17.1, \mathrm{C}_{2}, 31.7, \mathrm{C}_{4}, 29,8$; $\mathrm{C}_{6}, 109.7, \mathrm{C}_{7}, 113.5, \mathrm{C}_{8}, 119.2, \mathrm{C}_{5}, 120.1, \mathrm{C}_{9}-\mathrm{C}_{14}, 127.6-$ 128.1; $\quad \mathrm{C}_{15}-\mathrm{C}_{20}, 132.4-137.6 ; \quad \mathrm{C}_{21}, 143.2, \quad \mathrm{C}_{22}, 145.1$, $\mathrm{C}_{23}, 148.7, \mathrm{C}_{24}, 154.9, \mathrm{C}_{25}, 156.6, \mathrm{C}_{26}, 164.5$. Anal. Calcd for $\left(\mathrm{C}_{25} \mathrm{H}_{15} \mathrm{Cl}_{2} \mathrm{~N}_{5} \mathrm{O}\right)$ 471.3256: C, 63.709; H, 2.994; N, 14.859. Found: C, 63.73; H, 3.05; N, 14.81.

2.1.6.4 2-Cyanomethyl-5-Ethyl-1-(3,4-Dichloro-Phenyl) -1H-Benzo[f]Chromene[3,2e][1, 2, 4]Triazolo[1,5-c]Pyrimidine 7d Yield: 78\%. Mp: 202-204 ${ }^{\circ} \mathrm{C}$. IR: 3097, 2981, 2220, 1648, 1623, 1589, 1571, 1452, 783, $734 \mathrm{~cm}^{-1} .{ }^{1} \mathrm{H}-$ NMR $\left(300 \mathrm{MHz}, \mathrm{CDCl}_{3}+\mathrm{DMSO}_{6}\right) \delta: 7.93-8.11(\mathrm{~m}, 9 \mathrm{H})$, $6.67(\mathrm{~s}, 1 \mathrm{H}), 4.25(\mathrm{~s}, 2 \mathrm{H}), 2.56(\mathrm{~s}, 3 \mathrm{H}), 1.32(\mathrm{t}, 3 \mathrm{H}, \mathrm{J}=7.2)$. ${ }^{13} \mathrm{CNMR}\left(75 \mathrm{MHz}, \mathrm{DMSO}-\mathrm{d}_{6}+\mathrm{CDCl}_{3}\right.$ ) $\delta: \mathrm{C}_{1}, 20.7, \mathrm{C}_{2}, 26.3$, $\mathrm{C}_{3}, 35.1, \mathrm{C}_{4}, 103.3, \mathrm{C}_{6}, 116.0, \mathrm{C}_{7}, 118.5, \mathrm{C}_{8}, 122.7, \mathrm{C}_{5}, 125.4$, $\mathrm{C}_{9}-\mathrm{C}_{14}, 127.3-128.5, \quad \mathrm{C}_{15}-\mathrm{C}_{20}, 131.2-137.0, \quad \mathrm{C}_{21}, 145.7$, $\mathrm{C}_{22}, 147.3, \mathrm{C}_{23}, 151.8, \mathrm{C}_{24}, 153.7, \mathrm{C}_{25}, 159.2, \mathrm{C}_{26}, 164.3$. Anal. Calcd for $\left(\mathrm{C}_{26} \mathrm{H}_{17} \mathrm{Cl}_{2} \mathrm{~N}_{5} \mathrm{O}\right)$ 485.3524: $\mathrm{C}, 64.342 ; \mathrm{H}, 3.323$; N, 14.43. Found: C, 64.38; H, 3.29; N, 14.47.
2.1.7 Synthesis of 2-Cyanomethyl-Methylfuro[3,2-e][1,2,4] Triazolo[1,5-c]Pyrimidine 8 and 9

The method of preparation of these furotriazolopyranopyrimidines $\mathbf{8}$ and or $\mathbf{9}$ is the following. To a mixture of dry toluene $(200 \mathrm{~mL})$, Iminoether 5 or $6(2.96 \mathrm{~g}, 10 \mathrm{mmol})$ and Para-toluene sulfonic acid $(0.1 \mathrm{~g})$ as catalyst was added cyanoacetic acid hydrazide $(10 \mathrm{mmol})$. The mixture was heated under reflux in a Dean-Stark apparatus with removal of water and ethanol formed during 21-27 h. Evaporation of most of toluene left a residue which was dissolved in $20 \mathrm{~mL}$ of saturated solution of sodium bicarbonate and then extracted twice with $25 \mathrm{~mL}$ of chloroform. The organic layers was washed with $25 \mathrm{~mL}$ of saturated sodium chloride solution and then with $30 \mathrm{~mL}$ of distilled water and then dried over $\mathrm{MgSO}_{4}$. After removal of chloroform, the solid obtained was filtered and recrystallized from ethanol.

2.1.7.1 (5,9-Dimethyl-Furo[3,2,e][1,2,4]Triazolo[1,5-c] Pyrimidin-2-yl)-Acetonitrile 8a Yield: $67 \%$. Mp: $145{ }^{\circ} \mathrm{C}$. IR: 3076, 2987; 2221; 1651, 1621. ${ }^{1} \mathrm{H}-\mathrm{NMR}(300 \mathrm{MHz}$, DMSO-d $\left._{6}\right) \delta: 2.96\left(\mathrm{~s}, 3 \mathrm{H}, \mathrm{CH}_{3}\right) ; 4.74\left(\mathrm{~s}, 2 \mathrm{H}, \mathrm{CH}_{2}\right) ; 6.45(\mathrm{~s}$, 1H). ${ }^{13} \mathrm{C}-\mathrm{NMR}\left(75 \mathrm{MHz}, \mathrm{DMSO}-\mathrm{d}_{6}\right) \delta: \mathrm{C}_{1}, 20.7, \mathrm{C}_{2}, 22.5$, $\mathrm{C}_{3}, 23,1 ; \mathrm{C}_{5}, 114,8 ; \mathrm{C}_{7}, 117.1 ; \mathrm{C}_{6}, 120.8, \mathrm{C}_{8}, 138.2, \mathrm{C}_{9}, 141.9$, $\mathrm{C}_{10}, 148.8, \mathrm{C}_{11}, 157.3, \mathrm{C}_{12}, 164$. Anal. Calcd for $\left(\mathrm{C}_{11} \mathrm{H}_{9} \mathrm{~N}_{5} \mathrm{O}\right)$ 227.2261: C, 58.145; H, 3.992; N, 30.822. Found: C, 58.08; H, 4.12; N, 30.71 .

2.1.7.2 (5-Ethyl-9-Methyl-Furo[3,2,e][1,2,4]Triazolo[1,5-c] Pyrimidin-2-yl)-Acetonitrile 8b Yield: $65 \%$. Mp: $167{ }^{\circ} \mathrm{C}$. IR: 3083, 3000; 2223; 1646, 1627. ${ }^{1} \mathrm{H}-\mathrm{NMR}(300 \mathrm{MHz}$, DMSO-d $\left._{6}\right) \delta: 1.42\left(\mathrm{t}, 3 \mathrm{H}, \mathrm{CH}_{3}\right), 3.37\left(\mathrm{q}, 2 \mathrm{H}, \mathrm{CH}_{2}\right) ; 4.76$ (s, $\left.2 \mathrm{H}, \mathrm{CH}_{2}\right) ; 6.73(\mathrm{~s}, 1 \mathrm{H}) .{ }^{13} \mathrm{C}-\mathrm{NMR}\left(75 \mathrm{MHz}, \mathrm{DMSO}-\mathrm{d}_{6}\right)$ $\delta: \mathrm{C}_{1}, 20.7, \mathrm{C}_{2}, 22.1, \mathrm{C}_{3}, 22,5 ; \mathrm{C}_{4}, 26,4 \mathrm{C}_{5}, 116,1 ; \mathrm{C}_{7}, 117.4$; $\mathrm{C}_{6}, 120.3, \quad \mathrm{C}_{8}, 139.5, \quad \mathrm{C}_{9}, 143.2, \quad \mathrm{C}_{10}, 150.8, \mathrm{C}_{11}, 158.7$, $\mathrm{C}_{12}, 168$,6. Anal. Calcd for $\left(\mathrm{C}_{12} \mathrm{H}_{11} \mathrm{~N}_{5} \mathrm{O}\right)$ 241.2529: C, 59.743; H, 4.596; N, 29.03. Found: C, 59.78; H, 4.51; N, 29.21.

2.1.7.3 (5-Methyl-9-Methylsulfanyl-7H-Pyrazolo[4,3-e] [1,2,4]Triazolo[1,5,c]Pyrimidin-2-yl)-Acetonitrile 9a Yield: 76\%. Mp: 246-248 ${ }^{\circ} \mathrm{C}$. IR: 3093, 2984; 2223; 1646, 1627.


$\left.\mathrm{CH}_{3}\right), 3.23$ (s, $\left.3 \mathrm{H}, \mathrm{S}_{-} \mathrm{CH}_{3}\right), 3.58(\mathrm{~s}, 2 \mathrm{H}), 7.35-7.76(\mathrm{~m}, 5 \mathrm{H}$, $\mathrm{Ar}-\mathrm{H}, \mathrm{J}=7.2 \mathrm{~Hz}) .{ }^{13} \mathrm{C}-\mathrm{NMR}\left(75 \mathrm{MHz}, \mathrm{DMSO}-\mathrm{d}_{6}+\mathrm{CDCl}_{3}\right)$ $\delta: \mathrm{C}_{1}, 17.3, \mathrm{C}_{2}, 21.6, \mathrm{C}_{3}, 22.2, \mathrm{C}_{5}, 114.8, \mathrm{C}_{6}, 120.7, \mathrm{C}_{7}-$ $\mathrm{C}_{12}, 123.6-130.5, \quad \mathrm{C}_{13}, 140.2, \quad \mathrm{C}_{14}, 142.3, \quad \mathrm{C}_{15}, 147.4$, $\mathrm{C}_{16}, 161.6, \mathrm{C}_{17}, 165.8$. Anal. Calcd for $\left(\mathrm{C}_{16} \mathrm{H}_{13} \mathrm{~N}_{7} \mathrm{~S}\right)$ 335.3937: C, 57.299; H, 3.907; N, 29.234. Found: C, 57.30; $\mathrm{H}, 4.08 ; \mathrm{N}, 29.26$. 
2.1.7.4 (5-Ethyl-9-Methylsulfanyl-7H-Pyrazolo[4,3-e][1,2,4] Triazolo[1,5,c]Pyrimidin-2-yl)-Acetonitrile 9b Yield: $70 \%$. Mp: 253-255 ${ }^{\circ} \mathrm{C}$. IR: 3081, 2991; 2218; 1652, $1632 .{ }^{1} \mathrm{H}-$ NMR $\left(300 \mathrm{MHz}, \mathrm{DMSO}_{-} \mathrm{d}_{6}+\mathrm{CDCl}_{3}\right) \delta: 1.26(\mathrm{t}, 3 \mathrm{H}$, $J=7.2$ ), 3.18 (s, $3 \mathrm{H}, \mathrm{SCH}_{3}$ ), 2.65 (q, $2 \mathrm{H}, \mathrm{J}=7.2$ ), 3.67 (s, $2 \mathrm{H}), 7.35(\mathrm{~d}, 5 \mathrm{H}, \mathrm{Ar}-\mathrm{H}, J=7.2 \mathrm{~Hz}) .{ }^{13} \mathrm{C}-\mathrm{NMR}(75 \mathrm{MHz}$, DMSO- $\left.\mathrm{d}_{6}+\mathrm{CDCl}_{3}\right) \quad \delta: \mathrm{C}_{1}, 18.5, \mathrm{C}_{2}, 21.3, \mathrm{C}_{3}, 23.7, \mathrm{C}_{4}$, 31,$2 ; \mathrm{C}_{5}, 113.9, \mathrm{C}_{6}, 118.7, \mathrm{C}_{7}-\mathrm{C}_{12}, 124.3-131.7, \mathrm{C}_{13}, 142.6$, $\mathrm{C}_{14}, 144.1, \mathrm{C}_{15}, 148.7, \mathrm{C}_{16}, 163.4, \mathrm{C}_{17}, 168.1$. Anal. Calcd for $\left(\mathrm{C}_{17} \mathrm{H}_{15} \mathrm{~N}_{7} \mathrm{~S}\right)$ 349.4205: C, 58.436; H, 4.327; N, 28.06. Found: C, 58.44; H, 4.28; N, 28.19 .

\subsection{Antibacterial Screening for Furo, Pyrano, and Pyrazolo[3,2,e][1,2,4]Triazolo-[1,5-c] Pyrimidine 7,8 and 9}

Compounds 7a-c, 8a-b and 9a-b were examined for their antibacterial activity with paper disc $(\phi 5 \mathrm{~mm})$ method as described by [33-35] and compared with that of Tetracycline $\left(\mathrm{TE}_{30}, 54882,30 \mu \mathrm{g}\right)$, considered as reference. Strains used as test organisms in this study were; Salmonella typhimurium (ATCC14028: Source Département de génétique, Faculté de biologie, Université de Seville, Seville 41080, Espagne) Pseudomonas aeruginosa (Centre technique de l'agroalimentaire de Tunis) Escherichia coli (JW 1772) and Staphylococcus aureus (Centre technique de l'agroalimentaire de Tunis). Briefly, Tested compounds 7a-c, 8a-b and 9a-b were dissolved in a DMSO at different concentrations (1-54 M) as well as reference antibiotics $\mathrm{TE}_{30}(21 \mathrm{mg} / \mathrm{mL})$. Paper discs were soaked in each compound solution for 3-5 min a then transferred into the surface of growth media seeded with the test organism. After an incubation period $\left(24 \mathrm{~h}\right.$ at $\left.35^{\circ} \mathrm{C}\right)$, the diameters of the inhibition zones around the discs were measured ( $\mathrm{mm}$ ). Standard blank with no added test compounds was also analyzed. The obtained results are summarized in Tables 2 and 3. Table 3 summarizes the $\mathrm{TE}_{30}$ diameter of the inhibition zones against studied bacteria strains in a dimethylsulfoxide (DMSO).

\section{Results and Discussion}

\subsection{Synthesis}

The synthetic route of the triazolopyrimidines $\mathbf{7 , 8}$, and 9 is outlined in the Schemes 2, 3 and 4. "2-Amino-3-cyano4-methylfuran 1, 2-amino-3-cyano-pyrans 2, 1-Phenyl-3-thiomethyl-5-aminopyrazole-4-carbonitrile 3" were selected as our primary starting material for this synthesis and were prepared by methods taken from the literature [21-23], the reactivity of the cyanoacetic acid hydrazone has been already reported by the present authors [24, 28]. Compound
1, 2 and 3 reacted with excess of ethyl orthoester to yield iminoethers 4, 5 and 6 (Scheme 2), which were known to react with compounds containing $-\mathrm{NH}_{2}$ moiety such as hydrazides [4, 25-29].

In fact these precursors possess two reactive sites, a cyano group and an imidic carbon. These groups render them susceptible to react with cyanoacetic acid hydrazide in refluxing toluene with catalytic amount of $p$-toluenesulfonic acid to afford triazolopyrimidines $\mathbf{7 , 8}$ and $\mathbf{9}$. From the mechanistic view point and as shown in Scheme 1, tow plausible pathways and different intermediates and products could be expected. Indeed, the bis electrophilic character of iminoether $\mathbf{4}$ would allow a successive two nucleophilic additions of $-\mathrm{NH}_{2}$ group or of $\mathrm{NH}_{2}-\mathrm{NH}-$ moiety on the imidic carbon and the cyano group, which would give by intracyclisation via elimination of water to compound $\mathbf{7}$, and which was isolated in some cases when ethanol was used as solvent or amidopyranopyrimidines $\mathbf{7}^{\prime}$. Based on spectral data, the reaction was proceeded to produce pyranotriazolopyrimidine derivatives 7 rather than amidopyranopyrimidines $\mathbf{7}^{\prime}$. But iminoethers 5 and $\mathbf{6}$ would allow a successive two nucleophilic additions of $-\mathrm{NH}_{2}$ group or two nitrogen of $\mathrm{NH}_{2}-\mathrm{NH}-$ moiety on the imidic carbon and the cyano group, which would give respectively their intermediate (furano and pyrazolo)triazepines $8^{\prime}, 9^{\prime}$ and/or their isomers $8^{\prime \prime}, 9^{\prime \prime}$ that can be evolved by intramolecular cyclization via elimination of water to compounds furo(pyrazolo)triazolopyrimidine derivatives $\mathbf{8}$ and $\mathbf{9}$ (Scheme 3, Fig. 1, Table 1).

A plausible mechanism for the formation of triazolopyrimidines 7, 8 and 9 is depicted in Scheme 4. The transformation is believed to proceed via the nucleophilic attack of $-\mathrm{NH}_{2}$ group on the imidic carbon and the cyano group, giving rise to an imine intermediate. A subsequent intramolecular cyclization through the nucleophilic attack of the imino group on the carbonyl of the amide group, leads to the final.

\section{DFT Study}

\subsection{Computational Method}

Gaussian 09 has been employed for all the theoretical calculations [30]. Geometries of the molecules $\mathbf{7}^{\prime}, \mathbf{8}^{\prime}$ and $\mathbf{9}^{\prime}$ were optimized using the DFT at B3LYP level [31-34] along with $6-31 G(d, p)$ basis set. The molecule $7^{\prime}$ was calculated without $-\mathrm{Cl}$ in order to reduce the computational calcul. Stable minima of Ground state S0 geometries were confirmed by the absence of imaginary frequencies in the subsequent vibrational frequency calculations. The vibrational spectra of the compounds studied were calculated at the $B 3 L Y P / 6-31 G(d, p)$ optimized geometries. The torsional barriers around the $\mathrm{N}_{7}-\mathrm{N}_{6}-\mathrm{C}_{4}-\mathrm{C}_{3}$ and $\mathrm{N}_{19}-\mathrm{N}_{20}-\mathrm{C}_{21}-\mathrm{C}_{22}$ dihedral angle have been investigated with $B 3 L Y P / 3-21 G(d)$ 


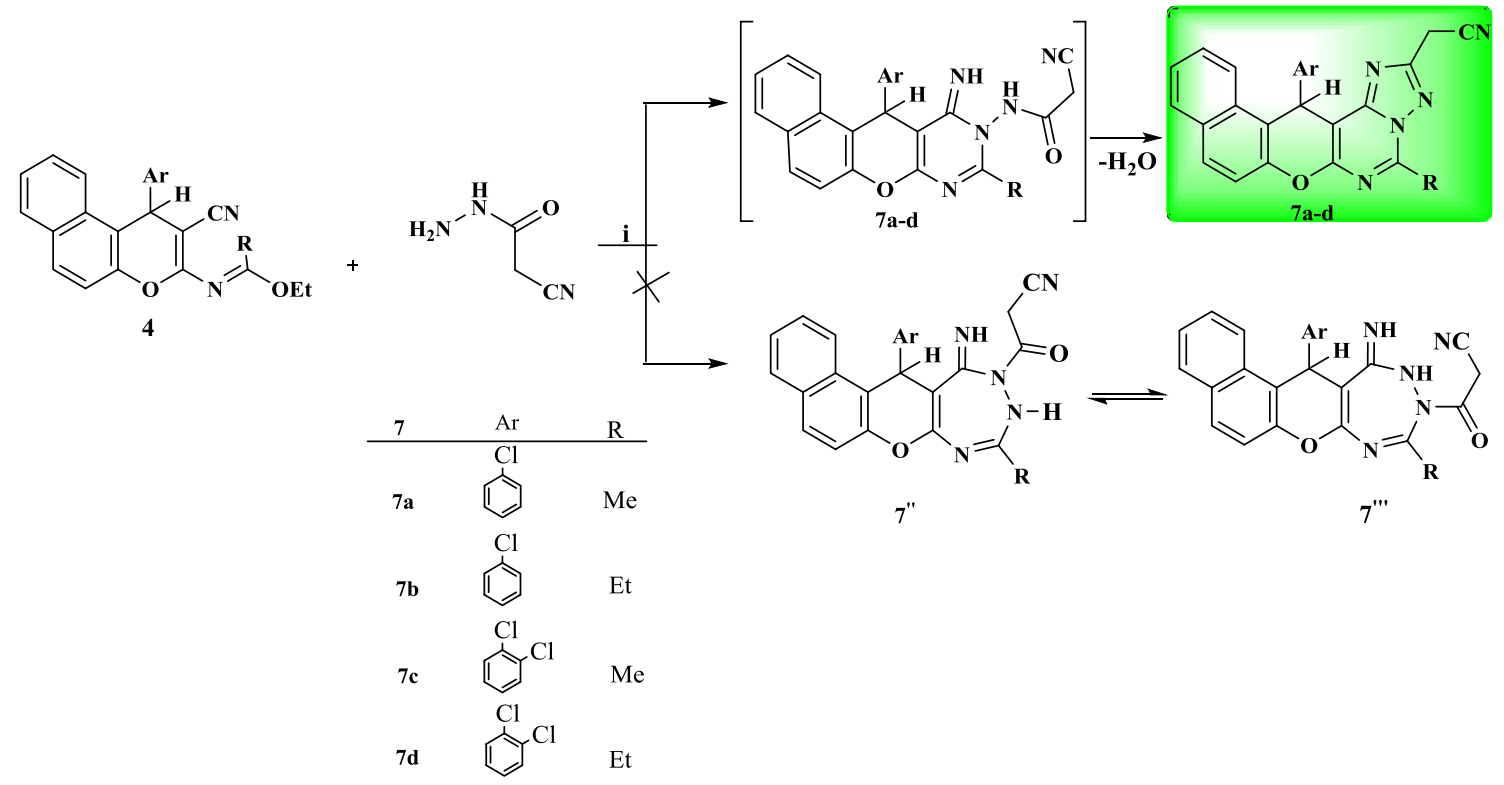

$\overbrace{\mathrm{N}}^{\mathrm{NC}}$<smiles>N#CCC(=O)NN</smiles><smiles>[Y9]/C(=N\c1c(C)c([Y])nn1-c1ccccc1)OCC</smiles>

6


i : TsOH ( cat), Toluene, reflux 22-26h

Scheme 3 Synthetic route for the title compounds 7,8 and 9 
<smiles>[R]C(=NC1=C(C#N)CCCC1)OCC</smiles><smiles>N#CCC(=O)NN</smiles>

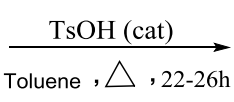<smiles>[R]c1nc2c(c(=N)n1NC(=O)CC)CC(C)CC2</smiles>

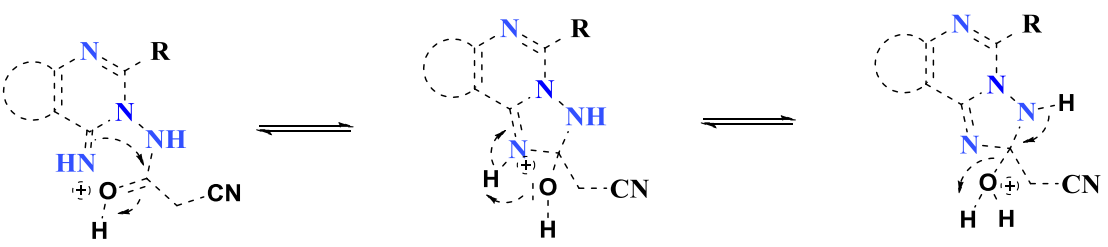

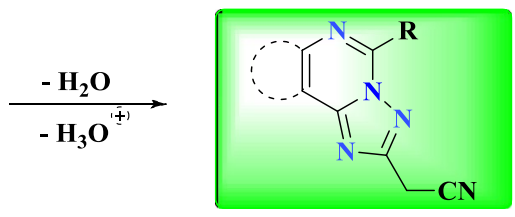

7,8 and 9



Scheme 4 A plausible mechanism for the formation of triazolopyrimidines $\mathbf{7 , 8}$ and 9

Fig. 1 Triazolopyrimidines $\mathbf{7}$, 8 and 9

for both compound $\mathbf{8}^{\prime}$ and $\mathbf{9}^{\prime}$ respectively (Figures). UV-Vis spectral was investigated at $T D-B 3 L Y P / 6-31 G(d, p)[19,20]$. All calculations were performed in the gas phase.

\subsection{Molecular Geometry}

Naphtopyrano, furo and pyrazolotriazolopyrimidine derivatives 7, 8 and 9 can theoretically exist in form conformational isomers represented below (Fig. 2) and make appear different types of intramolecular hydrogen bonds.

It should be noted that the analysis spectra of compounds $\mathbf{7}^{\prime}, \mathbf{8}^{\prime}$ and $\mathbf{9}^{\prime}$ carried out in $\mathrm{CDCl}_{3}$ have a single isomer alone; one of the three conformations is preferred. In order to determine the most stable conformation under which these compounds exist, a theoretical study carried out on compounds $7^{\prime}, \mathbf{8}^{\prime}$ and $9^{\prime}$ using the Gaussian 09 program carried out at the DFT (Functional Density Theory) level with the functional B3LYP29 was undertaken.

According to Brown's criterion, there are three classes of hydrogen bonds. Very strong, strong and weak depending on the distances and angles shown in the Table 2.

The existence of hydrogen bonding for these compounds is due to the presence of adjacent amide group, amino group and nitrile group in the aromatic ring. To know the impact of hydrogen bonding in defining conformational flexibility 
Table 1 Prepared synthesized triazolopyrimidines $\mathbf{7 , 8}$ and 9

\begin{tabular}{|c|c|c|c|c|}
\hline 7,8 and 9 & Ar & $\mathbf{R}$ & Time (h) & Yield (\%)* \\
\hline $7 a$ & & $\mathrm{Me}$ & 28 & 77 \\
\hline $7 b$ & & $\mathrm{Et}$ & 26 & 84 \\
\hline $7 c$ & & $\mathrm{Me}$ & 23 & 81 \\
\hline 7d & & $\mathrm{Et}$ & 25 & 78 \\
\hline $8 \mathbf{a}$ & - & $\mathrm{Me}$ & 20 & 67 \\
\hline $8 b$ & - & Et & 24 & 65 \\
\hline $9 a$ & - & $\mathrm{Me}$ & 26 & 76 \\
\hline $9 b$ & - & Et & 22 & 70 \\
\hline
\end{tabular}

*Yield calculated using the reaction of scheme (2)

of the molecule, B3LYP/3-21G(d) calculations were carried

The stable molecule corresponds to minimum energy out by applying rotations (Fig. 3).
Fig. 2 different types of intramolecular hydrogen bonds of triazolopyrimidines $\mathbf{7 , 8}$ and 9


III
<smiles>[R]c1nc2c(c(C)nn2-c2ccccc2)/c(=N\CC)n1N(N)C(=O)CC#N</smiles>

IV 
Table 2 Classes of hydrogen bonds

\begin{tabular}{llll}
\hline $\begin{array}{l}\text { Classes } \\
\text { Distances and } \\
\text { angles }\end{array}$ & $\begin{array}{l}\text { Very strong } \\
\text { H-A } \equiv \text { D-H }\end{array}$ & $\begin{array}{l}\text { Strong } \\
\text { H...A }>\text { D-H }\end{array}$ & $\begin{array}{l}\text { Weak } \\
\text { H...A } \gg D-H\end{array}$ \\
\hline $\mathrm{d}(\mathrm{H} . . \mathrm{A})(\AA)$ & $1.2-1.5$ & $1.5-2.2$ & $>2.5$ \\
$\Theta(\mathrm{D}-\mathrm{H} \ldots \mathrm{A})\left(^{\circ}\right)$ & $175-180$ & $130-180$ & $90-180$ \\
\hline
\end{tabular}

of the three molecules was calculated at $B 3 L Y P / 6-31 G$ (d). It was found that the molecule $\mathbf{9}^{\prime}$ was the most stable. The energies of the others were $-3,645,013.145$ and $-2,231,583.532 \mathrm{~kJ} \mathrm{~mol}^{-1}$ for molecule $\mathbf{7}^{\prime}$ and $\mathbf{8}^{\prime}$, respectively (Table 3).

The torsional barrier of molecule $\mathbf{8}^{\prime}$ showed that $\mathrm{C}_{4}=\mathrm{O}_{5}$ and $\mathrm{N}_{6}-\mathrm{H}_{16}$ were on the same side (Fig. 4). This result leads to the formation of intramolecular hydrogen $\mathrm{O}_{5} \ldots \mathrm{H}_{16}-\mathrm{N}_{6}$.

The torsional barrier of molecule $9^{\prime}$ showed that $\mathrm{N}_{19}-\mathrm{N}_{20}-\mathrm{C}_{21}-\mathrm{C}_{22}$ dihedral angle was $2.57 \AA$ (Fig. 5).

The fully optimized molecular structures of molecules $7^{\prime}$ and $\mathbf{8}^{\prime}$ with atomic numbering, calculated at B3LYP/6-31G $(d, p)$ level of the theory, are shown in Fig. 1. Selected calculated bond distances are given in Table 3. As seen from Table 4. Two intramolecular hydrogen $\mathrm{O} 5 \ldots \mathrm{H}_{16}-\mathrm{N}_{6}$ and
Table 3 The relative energies of compounds $7^{\prime}, 8^{\prime}$ and $\mathbf{9}^{\prime}$

\begin{tabular}{|c|c|c|c|}
\hline $\begin{array}{l}\text { B3LYP } \\
6-31 G(d, p)\end{array}$ & Molecule 7' & Molecule $8_{\text {III }}^{\prime}$ & Molecule $9_{\text {III }}^{\prime}$ \\
\hline $\begin{array}{l}\text { Energy/ } \\
\mathrm{kJ} \mathrm{mol}^{-1}\end{array}$ & $-3,645,013.145$ & $-2,231,583.532$ & $-3,873,610.11$ \\
\hline
\end{tabular}

$\mathrm{N}_{6} \ldots \mathrm{H}_{15}-\mathrm{N}_{14}$ for molecules were found. The presence of intramolecular Hydrogen significantly lowers the energy of the system and stabilizes the molecule. The stabilization of molecule is matched with the shortening of $\mathrm{O}_{5} \ldots \mathrm{H}_{16}-\mathrm{N}_{6}$ and $\mathrm{N}_{6} \ldots \mathrm{H}_{15}-\mathrm{N}_{14}$ distance. From the results of Table 3, it was observed that the calculated $\mathrm{C}_{4}=\mathrm{O}_{5}$ and $\mathrm{H}_{15}-\mathrm{N}_{14}$ bond distances of the molecule $\mathbf{9}^{\prime}$ reduced. This result showed that $-\mathrm{S}-\mathrm{CH}_{3}$ was responsible for the reduced of $\mathrm{C}_{4}=\mathrm{O}_{5}$ and $\mathrm{H}_{15}-\mathrm{N}_{14}$ bond distances.

\subsection{Electronic Structure and UV Spectrum}

$T D-B 3 L Y P / 6-31 G(d, p)$ based on $B 3 L Y P / 6-31 G(d, p)$ geometries was used to determine the low lying excited state of the molecule. Excitation energy, oscillator strength, and the main components of the ground state $\mathrm{S}_{0} \rightarrow$ excited

Fig. 3 Optimized structure at B3LYP/6-31G(d,p)



Molecule $7^{\prime}$

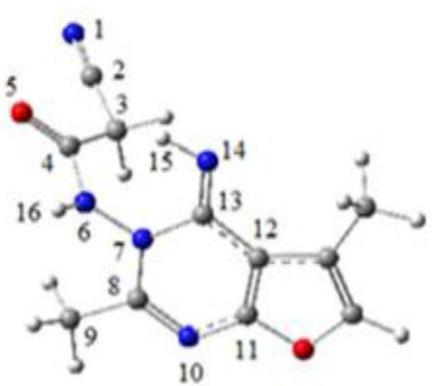

Molecule $8^{\prime}$



Molecule 9' 




Fig. 4 Torsional barrier of molecule $\mathbf{8}^{\prime}$ around the N-N-C-C dihedral angle at B3LYP/3-21G(d)

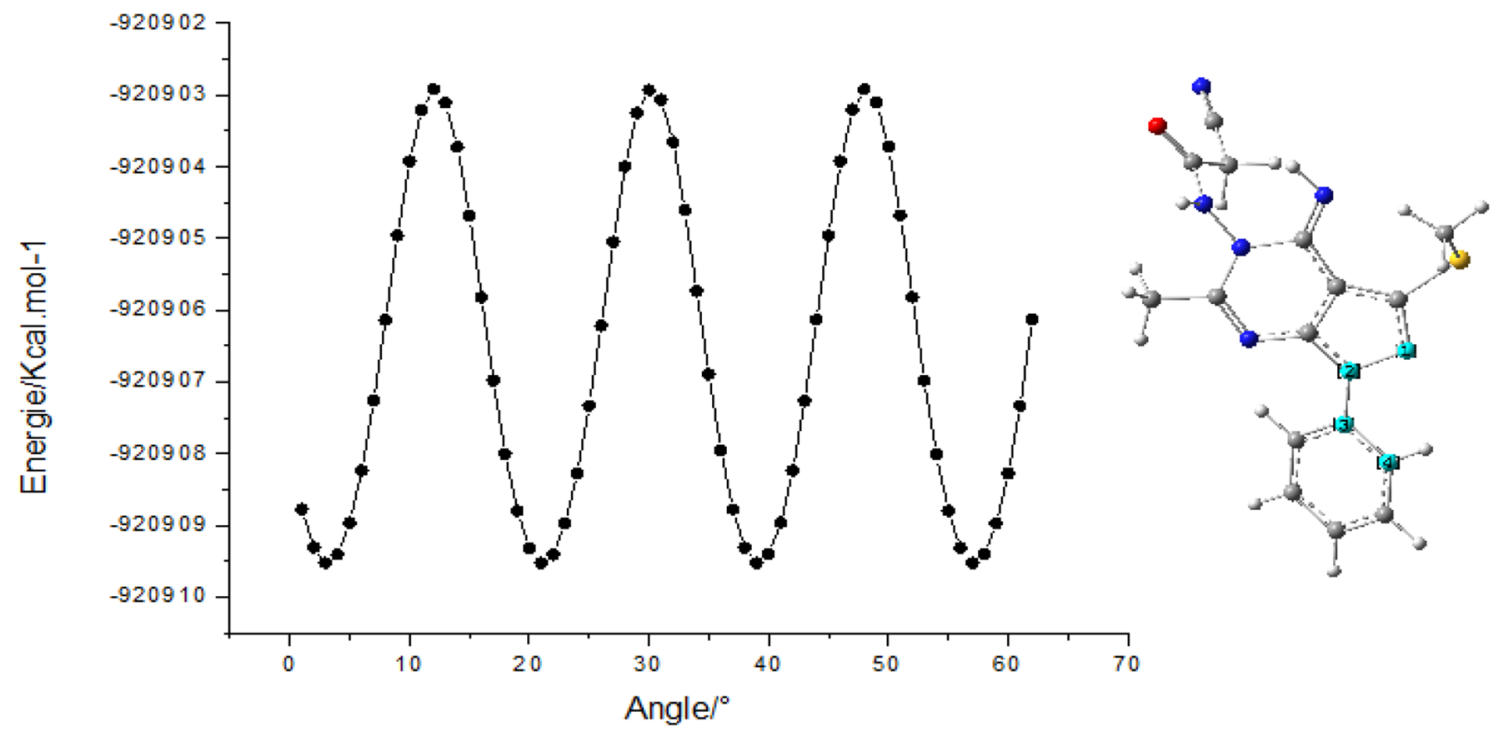

Fig. 5 Torsional barrier of molecule 9' around the N-N-C-C dihedral angle at B3LYP/3-21G(d)

Table 4 Geometrical parameters of molecule $7^{\prime}, \mathbf{8}^{\prime}$ and $\mathbf{9}^{\prime}$

\begin{tabular}{|c|c|c|c|}
\hline Bond length $\left(\mathrm{A}^{\circ}\right)$ & Molecule-7' & Molecule- $8_{\text {III }}^{\prime}$ & Molecule-9' \\
\hline N1...H15 & 5.413 & 5.397 & 5.435 \\
\hline N1...H16 & 5.551 & 5.556 & 5.539 \\
\hline O5...H16 & 2.44 & 2.450 & 2.448 \\
\hline N6...H15 & 2.375 & 2.38 & 2.343 \\
\hline O5...H15 & 3.275 & 3.316 & 3.311 \\
\hline S18...H15 & & & 4.562 \\
\hline $\mathrm{C} 4=\mathrm{O} 5$ & 1.210 & 1.211 & 1.210 \\
\hline N6-H16 & 1.015 & 1.015 & 1.015 \\
\hline H15-N14 & 1.019 & 1.020 & 1.019 \\
\hline
\end{tabular}

state $\mathrm{S}_{1}$ transition energy of each system are summarized in Table 5. The lowest excited states of the investigated structures is characterized by $\pi \rightarrow \pi^{*}$ transition from the highest occupied molecular orbital (HOMO) to the lowest unoccupied molecular orbital (LUMO). The $\pi \rightarrow \pi^{*}$ transition was observed for two molecule and caused by $\mathrm{C}=\mathrm{O}$ in amide group. The excitation energies decrease from $4.178 \mathrm{eV}$ for the molecule $\mathbf{8}^{\prime}$ to $3.689 \mathrm{eV}$ for the molecule $\mathbf{9}^{\prime}$. The main absorption peak of molecule $\mathbf{8}^{\prime}$ is blue-shifted with respect to the one of molecule 9' and 7' (Fig. 6). 
Table 5 Calculated maximum absorption wavelength $(\lambda)$, excitation energies $(\mathrm{E})$, oscillator strength (f) of molecule $\mathbf{7}^{\prime}, \mathbf{8}^{\prime}$ and $\mathbf{9}^{\prime}$ by the TD-DFT method

Fig. 6 Calculated UV-Vis spectra of different molecules at TD-DFT

\begin{tabular}{lllll}
\hline & $\begin{array}{l}\text { Calculated wave- } \\
\text { length }\end{array}$ & Energy $(\mathrm{eV})$ & Oscillator strength & Transition \\
\hline Molecule 7' & 336.49 & 3.684 & 0.0167 & $\mathrm{H} \rightarrow \mathrm{L} \mathrm{(97.13 \% )}$ \\
Molecule 8' & 296.71 & 4.178 & 0.1997 & $\mathrm{H} \rightarrow \mathrm{L}(97.82 \%)$ \\
Molecule 9' & 336.06 & 3.689 & 0.1066 & $\mathrm{H} \rightarrow \mathrm{L}(97.016 \%)$ \\
\hline
\end{tabular}



\subsection{The Frontier Molecular Orbitals of Molecules 7', $8^{\prime}$ and 9'}

The interested orbital in molecules are the frontier molecular orbital, highest occupied molecular orbital (HOMO) and lowest unoccupied molecular orbital (LUMO). Specific molecular orbital MO localization can be introduced by donor-acceptor molecules, while (LUMO) is localized on the acceptor unit and the (HOMO) is localized on the donor unit (Fig. 7).

The stabilization in (LUMO) is more pronounced than the stabilization in (HOMO), so that molecule $\mathbf{7}^{\prime}$ and $\mathbf{9}^{\prime}$ have smaller (HOMO-LUMO) gaps as compared to the molecule $\mathbf{8}^{\prime}$ (Table 6).

\subsection{Infrared Spectroscopy}

ATR-FTIR spectra of compounds $\mathbf{8}^{\prime}$ and $\mathbf{9}^{\prime}$ are presented in Fig. 8. They show the presence of two characteristic bands of the NH of the amin group and a broad band centered at 3344 and $3246 \mathrm{~cm}^{-1}$ associated with the $2 \times \mathrm{N}-\mathrm{H}$ stretching vibration, and an intense band at around $1680 \mathrm{~cm}^{-1}$ assigned to the vibration of the $\mathrm{C}=\mathrm{O}$ group. The spectra exhibited also a decrease of the intensities of the bands at $1450 \mathrm{~cm}^{-1}$, $1498 \mathrm{~cm}^{-1}$ and $1607 \mathrm{~cm}^{-1}$ attributed to the $\mathrm{C}=\mathrm{C}$ groups in the benzene ring. The $\mathrm{CN}$ stretching was observed at $2219 \mathrm{~cm}^{-1}$. The imine $(\mathrm{CH}=\mathrm{N})$ vibration corresponding to Schiff base formation was newly observed at $1622 \mathrm{~cm}^{-1}$ [28].

The experimental results were combined with theoretical data which describes molecular features. In computational studies, DFT method was also used to compute geometrical parameters, (HOMO) and (LUMO) energy levels by DFT/ B3LYP basis set in Gaussian 09 (Fig. 9) [36].

\section{Biological Activity}

All the title compounds derivatives $\mathbf{7 a - c}, \mathbf{8 a}-\mathbf{b}$ and $\mathbf{9 a}-\mathbf{b}$ were tested for their antibacterial activity Gram positive and Gram negative against four types of Bacteria and was measured by measuring the zone of inhibition in disc diffusion method (Table 7). 


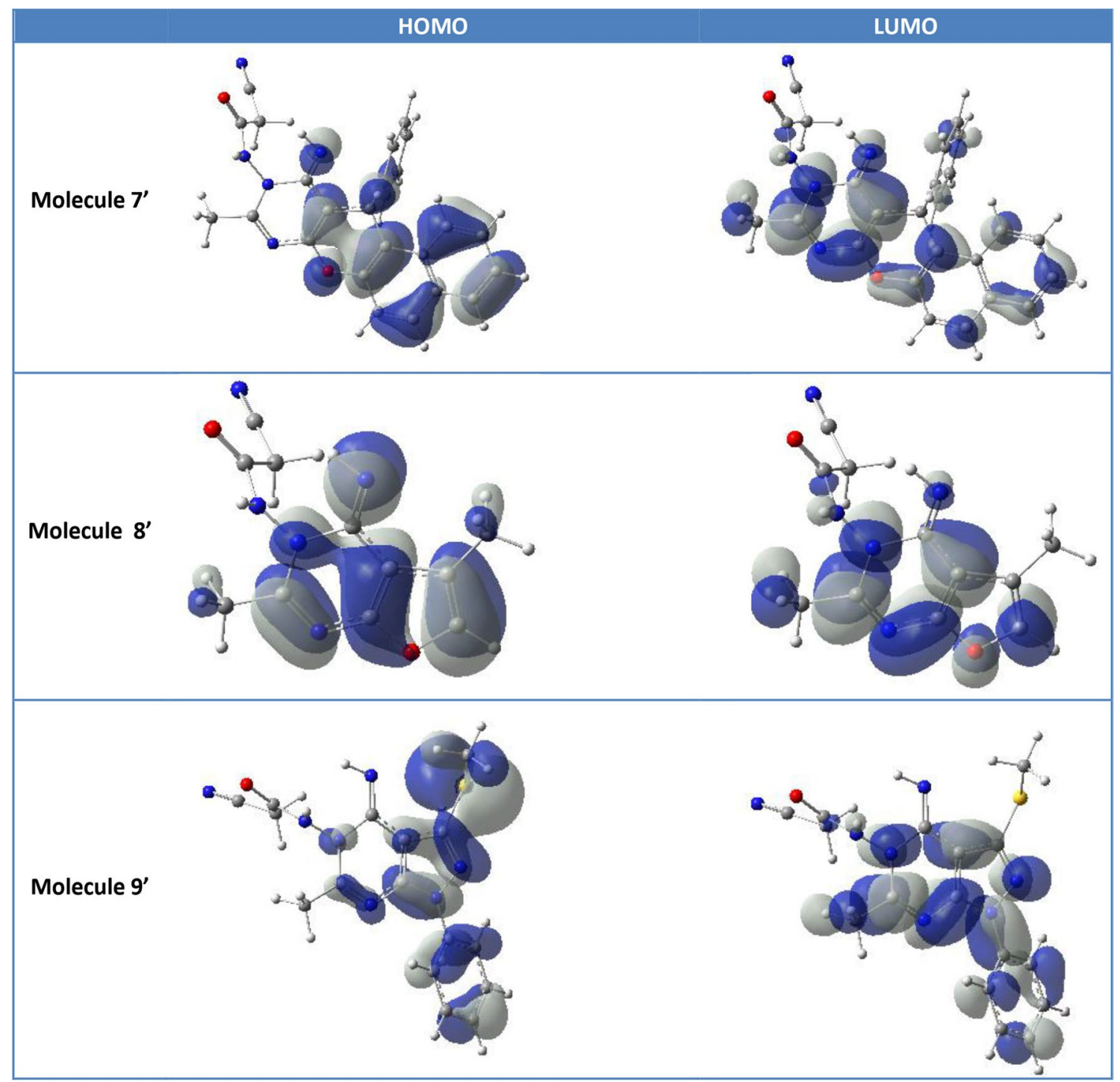

Fig. 7 B3LYP-calculated wave functions of the frontier molecular orbitals of molecules $\mathbf{7}^{\prime}, \mathbf{8}^{\prime}$ and $\mathbf{9}^{\prime}$

Table 6 Calculated HOMO, LUMO and energy gap $\mathrm{E}_{\mathrm{L}-\mathrm{H}}$ in $\mathrm{eV}$ at B3LYP/6-31G(d)

\begin{tabular}{lllr}
\hline & HOMO & LUMO & $\mathrm{E}_{\mathrm{L}-\mathrm{H}}$ \\
\hline Molecule 7' & -5.880 & -1.6035 & 4,2765 \\
Molecule 8' & -6.0385 & -1.4005 & 4638 \\
Molecule 9' & -5.941 & -1.697 & 4244 \\
\hline
\end{tabular}

The antibacterial activity was tested with the disc methods according to against Staphylococcus Pseudomonas, Escherichiacoli and Salmonella. This test is summarized by a resistance study of different compounds and standard antibiotic Tetracycline $\mathrm{TE}_{30}$. The colony diameter was noted after 3 days of incubation at $25^{\circ} \mathrm{C}$. Control received the same volume of sterilized distilled water. Bacteria growth was measured by averaging the three diameters taken at right angles for each colony. Percentage growth inhibition (\%) of bacteria colonies was calculated according to the following formula [37] Growth inhibition $(\%)=[($ Growth in control - Growth in treatment)/Growth in control] $\times 100$ : significant inhibition zone (IZ) results was taken in a range of lyses more than $10 \mathrm{~mm}$ and the minimum inhibitory concentrations (MIC) has been calculated. The highest active products were represented by the minimum inhibitory concentrations (MIC) (Fig. 10). 




Fig. 8 ATR-FTIR spectra of compounds $\mathbf{8}^{\prime}$ and $\mathbf{9}^{\prime}$

Results recorded in Table 8 showed the inhibition-diameter of compounds 7a-c, 8a-b and $\mathbf{9 a}-\mathbf{b}$ and reference TE30. Our results show that furano, pyrano, and pyrazolotriazolopyrimidine exhibited a moderate antibacterial activity against both Gram-positive and Gram-negative bacteria [38]. Importantly, pyranotriazolopyrimidine, 8a did not show any significant antibacterial activity against all used strains $(>36 \mathrm{mg} / \mathrm{mL})$ and no lyses plaque was observed with all concentrations used. Accordingly, compound $\mathbf{8 b}$ inactivate Staphylococcus and Salmonella with a high MIC ( $34.46 \mathrm{mg} / \mathrm{mL}$ ) whereas compound $\mathbf{9 a}$ and $\mathbf{9 b}$ seems to be more effective with a low MIC and a good IZ. With regard to the mechanism of antibacterial activity, one can speculate that compound $\mathbf{8 b}$ is not able to diffuse intracellular and to inhibit bacterial peptidoglycan. We note that adding a $\mathrm{CH}_{3}$ or $\mathrm{CH}_{2}-\mathrm{CH}_{3}$ in the fragment $\mathrm{R}$ decreases the activity. Furthermore, we noted that pyrazolotriazolopyrimidine $\mathbf{9 a}$ and 9b showed an inhibition zone at about 5 and $6.5 \mathrm{~mm}$ against Staphylococus. This result may be probably related to the presence of the phenyl group. Interestingly, compound $\mathbf{7 a}$ and $7 \mathbf{c}$ showed the highest inhibition zone at around $16 \mathrm{~mm}$ against Staphylococus and Pseudomonas. This result may be attributed to the presence of dihydronaphtho group [39-43] in the $\mathrm{R}$ ring. It is important to mention that all tested compounds, except $\mathbf{7 a}$ and $\mathbf{7 c}$ showed a low antibacterial activity in comparison to $\mathrm{TE}_{30}$ as can be noticed from Table 3 .

\section{Conclusions}

In conclusion, a new series of naphtopyrano, furo and pyrazolo[3,2,e][1,2,4]triazolo-[1,5-c]pyrimidine 7a-c, 8a-b and $\mathbf{9 a - b}$ were synthesized and the structure was characterized on the basis of their infrared (IR), NMR spectral data. All the title compounds were tested for their antibacterial
Fig. 9 ATR-FTIR spectra of compounds $\mathbf{8}^{\prime}$ and $\mathbf{9}^{\prime}$




Table 7 Prepared synthesized of compounds $\mathbf{7}(\mathbf{a}, \mathbf{c}), \mathbf{8}(\mathbf{a}, \mathbf{b})$ and $\mathbf{9}(\mathbf{a}, \mathbf{b})$
Fig. 10 Figures discs containing products synthesized by different concentrations

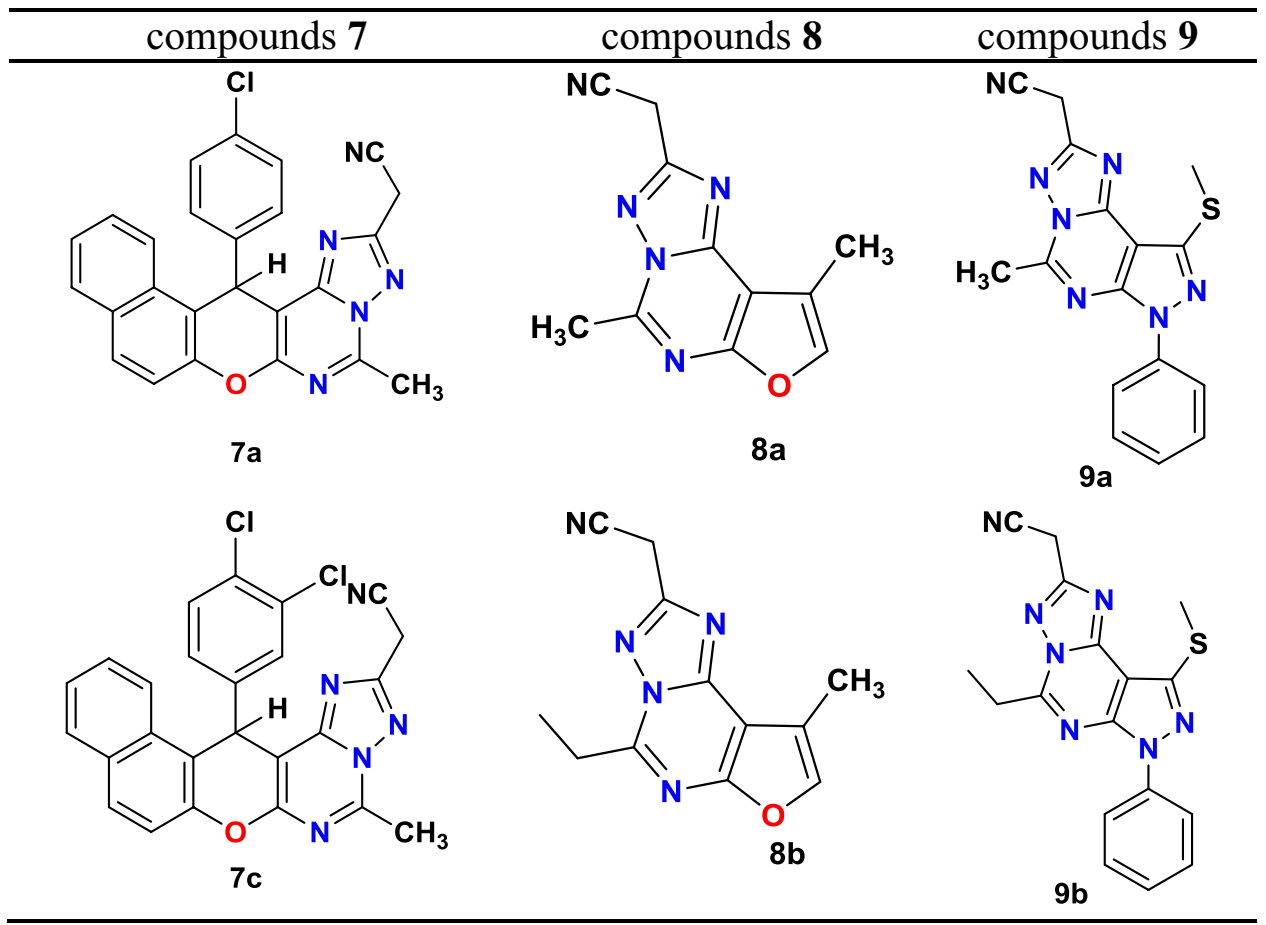

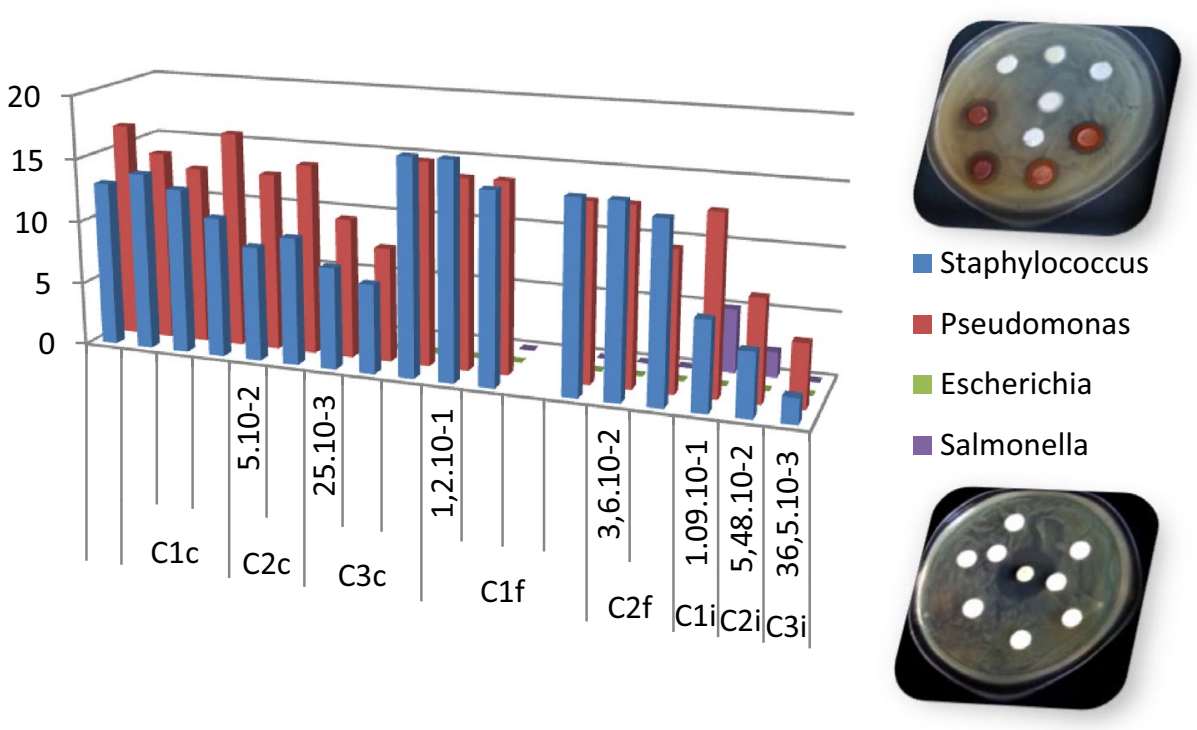

activity against four types of Bacteria. According to the results obtained, compounds $7 \mathbf{a}-\mathbf{c}, \mathbf{8 a}-\mathbf{b}$ and $\mathbf{9 a - b}$ exhibited a moderate in vitro antibacterial activity compared to the
$\mathrm{TE}_{30}$ reference. Naphtotriazolopyrimidine 7a and 7c showed the highest antibacterial activity. This can be attributed to the dihydronaphtho group. 
Table 8 Antibacterial activity of compounds $\mathbf{7}(\mathbf{a}, \mathbf{c}), \mathbf{8}(\mathbf{a}, \mathbf{b})$ and $\mathbf{9}(\mathbf{a}, \mathbf{b})$ as inhibition diameter or IZ Diameters (mm) and minimal inhibition concentration MIC $(\mathrm{mg} / \mathrm{mL})$

\begin{tabular}{|c|c|c|c|c|c|c|c|c|}
\hline & \multirow{2}{*}{\multicolumn{2}{|c|}{$\frac{\text { Gram+ }}{\text { Staphylococcus }}$}} & \multicolumn{6}{|l|}{ Gram- } \\
\hline & & & \multicolumn{2}{|c|}{ Pseudomonas } & \multicolumn{2}{|c|}{ Escherichia } & \multicolumn{2}{|c|}{ Salmonella } \\
\hline & $(\mathrm{mg} / \mathrm{mL})$ & $(\mathrm{mm})$ & $(\mathrm{mg} / \mathrm{mL})$ & $(\mathrm{mm})$ & $(\mathrm{mg} / \mathrm{mL})$ & $(\mathrm{mm})$ & $\overline{(\mathrm{mg} / \mathrm{mL})}$ & $\overline{(\mathrm{mm})}$ \\
\hline $7 \mathrm{a}$ & 16.74 & 15.56 & 16.74 & 14.78 & - & - & & - \\
\hline $7 \mathrm{c}$ & 18.53 & 16.13 & 18.53 & 15.11 & - & - & & - \\
\hline $8 \mathrm{a}$ & 36.67 & 3.52 & 36.67 & 2.63 & - & - & 36.67 & 1.57 \\
\hline $8 b$ & 34.46 & 4.06 & 34.46 & 3.83 & - & - & 34.46 & 3.14 \\
\hline $9 \mathrm{a}$ & 18.92 & 5 & 18.92 & 5 & - & - & - & - \\
\hline $9 b$ & 16.52 & 6.5 & 16.52 & 6.5 & - & - & - & - \\
\hline TE30 $(30 \mu \mathrm{g})$ & 21 & 26 & 21 & 21 & 21 & 24 & 21 & 22 \\
\hline
\end{tabular}

Open Access This article is distributed under the terms of the Creative Commons Attribution 4.0 International License (http://creativeco mmons.org/licenses/by/4.0/), which permits unrestricted use, distribution, and reproduction in any medium, provided you give appropriate credit to the original author(s) and the source, provide a link to the Creative Commons license, and indicate if changes were made.

\section{References}

1. Wang XS, Yang GS, Zhao G (2008) Enantioselective synthesis of naphthopyran derivatives catalyzed by bifunctional thioureatertiary amines. Tetrahedron Asymmetry 19(6):709-714. https:// doi.org/10.1016/j.tetasy.2008.02.018

2. Fakher C, Mehdi M, Hédi BM, Leila CG, Mansour S (2007) Synthesis and antigenotoxic activity of some naphtho[2,1-b] pyrano[3,2-e][1,2,4]triazolo[1,5-c]pyrimidine derivatives. Eur J Med Chem 42(5):715-718. https://doi.org/10.1016/j.ejmec h.2006.12.002

3. Mutchu BR, Kotra V, OntedduSR Boddapati SNM, Bollikolla HB (2019) Synthesis, cytotoxicity and antimicrobial evaluation of some new 2-Aryl,5-substituted 1,3,4-oxadiazoles and 1,3,4-thiadiazoles. Chem Afr 2:15-20. https://doi. org/10.1007/s42250-018-00034-x

4. Mantoani SP, Chierrito TPC, Vilela AFL, Cardoso CL, Martínez A, Carvalho I (2016) Novel triazole-quinoline derivatives as selective dual binding site acetylcholinesterase inhibitors. Molecules 21(2):193. https://doi.org/10.3390/molecules210201 93

5. Bedair AH, Emam HA, El-Hady NA, Ahmed KAR, El-Agrody AM (2001) Synthesis and antimicrobial activities of novel naphtho[2,1-b]pyran, pyrano[2,3-d]pyrimidine and pyrano[3,2e] $[1,2,4]$ triazolo[2,3-c]-pyrimidine derivatives. ILFarmaco 56(12):965-973. https://doi.org/10.1016/S0014-827X(01)01168-5

6. Amole KL, Bello IA, Oyewale AO (2019) Synthesis, characterization and antifungal study of five new derivatives of E-1-(--hydroxyphenyl)chalcone. Chem Afr 2:1-14. https://doi.org/10.1007/ s42250-018-0027-3

7. Musiol R, Jampilek J, Buchta V, Silva L, Niedbala H, Podeszwa B, Palka A, Majerz-Maniecka K, Oleksyn B, Polanski J (2006) Antifungal properties of new series of quinoline derivatives. Bioorg Med Chem 14(10):3592-3598. https://doi.org/10.1016/j. bmc.2006.01.016

8. Johnson TC, Martin TP, Mann RK, Pobanz MA (2009) Penoxsulam structure activity relationships of triazolopyrimidine sulfonamides. Bioorg Med Chem 17(12):4230-4240. https://doi. org/10.1016/j.bmc.2009.02.010
9. Bruno O, Brullo C, Schenone S, Bondavalli F, Ranise A, Tognolini M, Ballabeni V, Barocelli E (2004) Synthesis and pharmacological evaluation of $5 \mathrm{H}$-[1]benzopyrano[4,3-d]pyrimidines effective as antiplatelet/analgesic agents. Bioorg Med Chem 12(3):553-561. https://doi.org/10.1016/j.bmc.2003.11.018

10. Rashad AE, Heikal OA, Elnezhawy AOA, Abdelmegeid FM (2005) Synthesis and isomerization of thienotriazolopyrimidine and thienotetrazolopyrimidine derivatives with potential antiinflammatory activity. Heteroat Chem 16(3):226-234. https:// doi.org/10.1002/hc.20114

11. Chen WB, Jin GY (2003) Syntheses and biological activities of $S$-1,2,4-triazolo (1,5-a) pyrimidinylalkyl dithiophosphates. Heteroat Chem Int J Main Group Elements 14(7):607-611. https:// doi.org/10.1002/hc.10198

12. Martin-Kohler A, Widmer J, Bold G, Meyer T, Sequin U, Traxler P (2004) Furo [2,3-d] pyrimidines and oxazolo [5,4-d] pyrimidines as inhibitors of receptor tyrosine kinases (RTK). Helv Chim Acta 87(4):956-975. https://doi.org/10.1002/hlca.200490089

13. Isloor AM, Kalluraya B, Shetty P (2009) Regioselective reaction: synthesis, characterization and pharmacological studies of some new Mannich bases derived from 1,2,4-triazoles. Eur J Med Chem 44(9):3784-3787. https://doi.org/10.1016/j.ejmech.2009.04.038

14. Kumar R, Nair RR, Dhiman SS, Sharma J, Prakash O (2009) Organoiodine (III)-mediated synthesis of 3-aryl/heteroaryl-5, 7-dimethyl-1, 2, 4-triazolo [4, 3-c] pyrimidines as antibacterial agents. Eur J Med Chem 44(5):2260-2264. https://doi. org/10.1016/j.ejmech.2008.06.004

15. Bruno O, Brullo C, Schenone S, Bondavalli F, Ranise A, Tognolini M, Barocelli E (2006) Synthesis, antiplatelet and antithrombotic activities of new 2-substituted benzopyrano [4, 3-d] pyrimidin-4-cycloamines and 4-amino/cycloamino-benzopyrano [4, 3-d] pyrimidin-5-ones. Bioorg Med Chem 14(1):121-130. https://doi. org/10.1016/j.bmc.2005.07.066

16. Savini L, Chiasserini L, Pellerano C, Filippelli W, Falcone G (2001) Synthesis and pharmacological activity of 1,2,4-triazolo [4,3-a] quinolines. IL Farmaco 56(12):939-945. https://doi. org/10.1016/S0014-827X(01)01166-1

17. Abd El-Wahab AH (2012) Synthesis, reactions and evaluation of the antimicrobial activity of some 4-(p-Halophenyl)-4H-naphthopyran, pyranopyrimidine and pyranotriazolopyrimidine derivatives. Pharmaceuticals 5(7):745-757. https://doi.org/10.3390/ ph5070745

18. Dridi K, El Efrit ML, Zantour H (1999) Action d'amines et de derives d'hydrazines sur les $\mathrm{N}$-(3-carbetoxy-2-thieny) imino ethers: synthese de thieno [2,3-d] pyrimidin-4 (3H)-ones. J Soc Chim Tunis 5:387-392 
19. Adamo C, Jacquemin D (2013) The calculations of excited-state properties with time dependent density functional theory. Chem Soc Rev 42(3):845-856. https://doi.org/10.1039/c2cs35394f

20. Gierschner J, Cornil J, Egelhaaf HJ (2007) Optical bandgaps of $\pi$-conjugated organic materials at the polymer limit: experiment and theory. Adv Mater 19(2):173-191. https://doi.org/10.1002/ adma.200600277

21. Mkaouar K, Chabchoub F, Samadi A, Marco CJ, Salem M (2011) A novel Synthesis of 14-aryl-14 h-naphto [2,1-b] pyrano[3,2-e][1,2,4]triazolo[1,5-c]pyrimidines. Heterocycl Lett 1(2):96-105

22. Gatta F, Del Giudice MR, Borioni A, Borea PA, Dionisotti S, Ongini E (1993) Synthesis of imidazo [1, 2-c] pyrazolo [4, 3-e] pyrimidines, pyrazolo [4, 3-e] 1, 2, 4-triazolo [1, 5-c] pyrimidines and 1, 2, 4-triazolo [5, 1-i] purines: new potent adenosine A2 receptor antagonists. Eur J Med Chem 28(7-8):569-576. https://doi.org/10.1016/0223-5234(93)90087-U

23. Shaker RM (2006) The chemistry of mercapto-and thione-substituted 1,2,4-triazoles and their utility in heterocyclic synthesis. Arkivoc 9:59-112

24. Pyo JI, Hwang EJ, Cheong CS, Lee SH, Lee SW, Kim IT, Lee SH (2005) Synthesis and photoluminescent properties of novel furopyrimidine derivatives. Synth Met 155(3):461-463. https:// doi.org/10.1016/j.synthmet.2005.06.017

25. Wu H, Feng JT, Lin KC, Zhang X (2012) Synthesis and herbicidal activity of substituted pyrazole isothiocyanates. Molecules 17(10):12187-12196. https://doi.org/10.3390/molecules171012 187

26. Gorobets NY, Yousefi BH, Belaj F, Kappe CO (2004) Rapid microwave-assisted solution phase synthesis of substituted 2-pyridone libraries. Tetrahedron 60(39):8633-8644. https:// doi.org/10.1016/j.tet.2004.05.100

27. Dridi KM, Said RB, Arfaoui Y, Al-Ayed AS (2013) Activated bentonite promoted Friedländer condensation reactions: synthesis of thieno [2, 3-b] quinolinones and tacrines analogues derivatives. Eur J Chem 4(3):216-219. https://doi.org/10.5155/ eurjchem.4.3.216-219.788

28. Jabli D, Dridi K, El Efrit ML (2014) A convenient synthesis of new 2-cyanomethylthieno [3,2-e][1,2,4]-triazolo [1,5-c] pyrimidine derivatives. Lett Org Chem 11(6):403-408

29. Todde S, Moresco RM, Simonelli P, Baraldi PG, Cacciari B, Spalluto G, Magni F (2000) Design, radiosynthesis, and biodistribution of a new potent and selective ligand for in vivo imaging of the adenosine A2A receptor system using positron emission tomography. J Med Chem 43(23):4359-4362. https:// doi.org/10.1021/jm0009843

30. Frisch MJ, Trucks GW, Schlegel HB, Scuseria GE, Robb MA, Cheeseman JR, Scalmani G, Barone V, Mennucci B, Petersson GA, Nakatsuji H (2009) Gaussian 09, R.A. Gaussian Inc., Wallingford CT 121, pp 150-166

31. Lee C, Yang W, Parr RG (1988) Development of the Colle-Salvetti correlation-energy formula into a functional of the electron density. Phys Rev B 37(2):785-789. https://doi.org/10.1103/ PhysRevB.37.785
32. Becke AD (1993) Density-functional thermochemistry. III. The role of exact exchange. J Chem Phys 98(7):5648-5652. https:// doi.org/10.1063/1.464913

33. Vural H, Uçar I (2016) A mixed experimental and theoretical study on chelidamate copper(II) complex with 4-methylpyrimidine. J Coord Chem 69(20):3010-3020. https://doi.org/10.1080/00958 972.2016 .1225042

34. Azhagiri S, Jayakumar S, Gunasekaran S, Srinivasan S (2014) Molecular structure, Mulliken charge, frontier molecular orbital and first hyperpolarizability analysis on 2-nitroaniline and 4-methoxy-2-nitroaniline using density functional theory. Spectrochim Acta Part A Mol Biomol Spectrosc 124:199-202. https://doi. org/10.1016/j.saa.2013.12.106

35. Milad R, Essalah K, Abderrabba M (2018) Optoelectronic and conductivity of $\pi$-conjugated polymers based on phenylenevinylene, 1,3,4-thiadiazole and thiophene: suitable candidates for n-type organic semiconductors. J Phys Org Chem 31(2):e3750. https://doi.org/10.1002/poc.3750

36. El Bakri Y, Lai CH, Sebhaoui J, Ben Ali A, Essassi EM, Mague JT (2019) Synthesis, spectroscopic characterization, thermal, XRD crystal structure, the PLATON structural analysis, and theoretical studies of a new 1,2,4-triazolo-[1,5-a]pyrimidines derivatives. J Mol Struct 1184:12-24. https://doi.org/10.1016/j.molst ruc.2019.01.071

37. Jabeen K, Javaid A (2008) Antifungal activity of aqueous and organic solvent extracts of allelopathic trees against Ascochyta rabiei. Allelopathy J 22:231-238

38. Jabli D, Lahbib K, Dridi K, Efrit M L (2015) Antibacterial Study Novel 2-cyanomethylthieno [3,2-e] [1,2,4]- triazolo[1,5-c]pyrimidine. J Pharm Chem Biol Sci 3(2): 178-187

39. Abdel-Megeid FME, Hassan NA, Zahran MA, Rashad AE (1998) Synthesis of 5,6-dihydronaphtho $1^{\prime}, 2^{\prime}: 4,5$ thieno 2,3-d pyrimidines, 5,6-dihydronaphtho $1^{\prime}, 2^{\prime}$ : 4,5 thieno3,2-e 1,2,4 triazolo 1,5-c pyrimidines, and some of their nucleosides. Sulfur Lett 21(6):269-284

40. Chen H, Yan K (2011) 6-Benzyl-2-[(triphenyl- $\lambda 5$ phosphanylidene) amino]-4, 5, 6, 7-tetrahydrothieno [2, 3-c] pyridine-3-carbonitrile. Acta Crystallogr Sect E Struct Rep Online 67(10):o2548-o2548. https://doi.org/10.1107/S16005368110350 82

41. Murray PR, Baron EJ, Jorgensen JH, Pfaller MA, Yulken RH (2003) Manual of clinical microbiology. American Society for Microbiology Press, Washington, DC, p 1212

42. Delost MD (1997) Introduction to diagnostic microbiology: a text and workbook. Louis, Mosby Inc, St, p 552

43. Al-Taisan KM, Al-Hazimi H, Al-Shihry SS (2010) Synthesis, characterization and biological studies of some novel thieno [2, 3-d] pyrimidines. Molecules 15(6):3932-3957. https://doi. org/10.3390/molecules 15063932 